\title{
Middle to late Miocene sequence stratigraphy of the Transylvanian Basin (Romania)
}

\author{
Cs. Krézsek ${ }^{\mathrm{a}}$, S. Filipescu ${ }^{\mathrm{b}}$ * \\ ${ }^{\text {a }}$ Romgaz, Str. Unirii 4, 551025 Mediaş, Romania \\ ${ }^{b}$ Babeş-Bolyai University, Department of Geology, Str. Kogălniceanu 1, 400084 Cluj-Napoca, Romania \\ *Corresponding author. Fax: +40 264 591906. E-mail address: sorin@bioge.ubbcluj.ro (S. Filipescu).
}

\begin{abstract}
The history of Middle to Late Miocene evolution of the Transylvanian Basin was determined by the bordering Carpathian orogen evolution, the tectonic events being well recorded by the sedimentary history. The basin evolved in a back-arc setting, under a regional, compressional stress field. The major tectonic events produced during the Late Sarmatian and Post-Pannonian were related to the reactivation of the pre-Badenian fault systems. The Transylvanian Basin got uplifted after the Late Pannonian (? during the Pliocene), and at least $500 \mathrm{~m}$ of sedimentary cover was eroded. Based on seismic and well-log interpretation, core and outcrop sedimentology, and microfauna, eight sequences were defined. The early Middle Miocene sequences are roughly synchronous to five $3 \mathrm{rd}$ order global sea-level cycles. Most of the recognized sequence boundaries are enhanced by regional tectonic events. The sedimentary evolution was also strongly influenced by salttectonics, active starting with the Late Sarmatian. Two sequences were identified in the Lower Badenian deposits. The third sequence (late Early Badenian to early Mid Badenian) preserves information about deeper shelf settings. The lowstand of the following sequence was responsible for the deposition of the salt formation (late Mid Badenian), an important lithostratigraphic marker in the sedimentary record of the basin. In general, the Upper Badenian deposits (parts of the 4th and 5th sequences) belong to deep marine submarine fan systems. The Sarmatian (partially 5th, 6th and partially 7th sequences) was characterized by diverse salinity conditions, stretching from brackish to hypersaline, and by high tectonic instability, which induced several significant relative sea-level falls. During that time, deltaic north) and fandeltaic (east) systems fed submarine fans, stacked between salt-related submarine heights ("channeled" deepmarine depocenters). Most of the Pannonian deposits (partially 7th and 8th sequences) belong to submarine fan systems, but shallower facies were also found in the western and eastern part of the basin.
\end{abstract}

Keywords: Transylvanian Basin; Miocene; Sequence stratigraphy; Microfauna; Sedimentology

\section{Introduction}

Starting from the Late Oligocene, the Alpine-Carpathian orogen evolution and related uplift induced several episodes of isolation and limited connection of episutural and perisutural basins (Bally and Snelson, 1980) from the Tethys Ocean. This huge inland sea, once stretched from the Western Alps to the Aral Sea, is known as the Paratethys. The isolation caused endemic faunal evolution and separation of regional stages (Rögl, 1998). Three Paratethyan domains were defined based on these differences: Western, Central and Eastern (Fig. 1). The Transylvanian 
Basin, together with other intra-Carpathian basins (Vienna, Slovakian, Pannonian, etc.) represents parts of Central Paratethys, and for this reason we use the corresponding regional stages (Fig. 2; and refer to Table 1 for the correlation to the standard stages).

During the Middle to Late Miocene, the intra-Carpathian basins formed uniform aquatic bioprovinces for several times, but the basins themselves encountered particular tectonic and sedimentary evolution. Several authors discussed the Miocene sequence stratigraphic evolution of various intra-Carpathian basins during the past 20 years (Pogácsás et al., 1988; Vakarcs et al., 1994, 1998; Juhász et al., 1997; Magyar et al., 1999b; Sacchi et al., 1999; Kováč et al., 1998, 1999, 2001), but only a few data have been published related to the sequence stratigraphy of the Transylvanian Basin (Hosu and Filipescu, 1996; Filipescu and Gîrbacea, 1997).

The tectonic data indicate that for the Mid to Late Miocene there are more differences than similarities between the Transylvanian Basin and the other intra- Carpathian basins: while the Styrian basin (Sachsenhofer, 1996), the Vienna basin (Decker, 1996) or the Pannonian Basin (Tari, 1994; Csontos, 1995; Tari and Horváth, 1995; Bada, 1999; Fodor et al., 1999; Tari et al., 1999) had extensional backarc-type evolution, the Transylvanian Basin evolved under a regional compressional stress field (De Broucker et al., 1998; Ciulavu, 1999; Huismans, 1999).

Filling of the Transylvanian Basin was strongly related to the evolution of the bordering Carpathian orogen, therefore the sedimentary record preserves valuable information about the Carpathian's tectonic history (Vancea, 1960; Ciupagea et al., 1970; De Broucker et al., 1998; Ciulavu, 1999; Huismans, 1999).

Our purpose is to present the sequence stratigraphic features of the Middle to Upper Miocene sedimentary record of the Transylvanian Basin, and to discuss some characteristic features of the basin subsidence.

\section{Geological setting}

The Transylvanian Basin is a Late Cretaceous to Neogene intra-Carpathian episutural (Bally and Snelson, 1980) sedimentary basin, which got its roughly circular shape during the Late Miocene to Pliocene. It is bordered by the Eastern and Southern Carpathians and separated from the Pannonian Basin by the Apuseni Mountains (Fig. 2).

The Transylvanian Basin's basement is shared with the eastern Pannonian basin, and is built by a stack of thrust sheets assembled by Mid-Cretaceous (Săndulescu, 1984; 1988). The basin's evolution was strongly related to the Carpathians history (Burchfiel, 1976). During the Cenozoic, the basin's basement represented the backstop of the Carpathian thrust and folded belt (Săndulescu, 1984, 1988).

The collapse of the Middle Cretaceous orogen (Ciulavu and Bertotti, 1994; Huismans et al., 1997; Huismans, 1999; Sanders, 1999; Willingshofer et al., 1999, 2001) triggered the formation of extensional to transtensional rift systems (Krézsek and Bally, submitted for publication), which were filled by a relatively thick succession of dominantly Gosau-type clastic deposits (Lupu and Lupu, 1983). The half-grabens were inverted by the Cretaceous/Paleogene boundary, inducing coarse-grained alluvial fan-type sedimentation during the Paleocene (Hosu, 1999). The sedimentation was confined to interconnected piggy-back basins. During the Eocene, low rate of basin subsidence supported the development of carbonate platforms (Rusu, 1995; Proust and Hosu, 1996). The dominantly shallow-marine sedimentation was interrupted by two continental "events", which indicate compressional reactivations of the basin's fault systems (Hosu, 1999).

Major tectonic changes occurred at the beginning of Late Oligocene. The continental escape of the Eastern Alps (Ratschbacher et al., 1991) triggered major block rotations (Csontos, 1995; Panaiotu, 1998; Fodor et al., 1999; Márton and Fodor, 2003). This was also reflected in the sedimentation of the piggy-back basins by a progressive shifting from shallow carbonate-type platforms (Eocene) to fluvial and siliciclastic ramp environments (Oligocene). Increased deepening was also recorded in the "Transcarpathian Basin", produced by the start of compressional tectonics 
of the Pienides (Săndulescu, 1984, 1988). The Early Miocene final closure of the "Transcarpathian Basin" induced thrusting of Pienide nappe systems in the northern Transylvanian Basin (Săndulescu, 1984; De Broucker et al.,1998; Ciulavu, 1999). Thrusting generated flexural downbending of the (present) northern Transylvanian Basin's basement and created a retro-foreland type basin (Györfi et al., 1999), which was filled during the Early Miocene by coarse-grained fandeltas.

Major tectonic changes occurred at the beginning of Middle Miocene (Badenian). From this time onward, the Transylvanian Basin continued its evolution in a back-arc setting, squeezed between the extensional back-arc Pannonian Basin (Tari, 1994; Vakarcs et al., 1994, 1998; Tari and Horváth, 1995), and the compressional Carpathian folded and thrust belt (Săndulescu, 1984, 1988). The basin evolved under a regional northeast to southwest or east to west oriented compressional stress field (Ciulavu, 1999), characterized by a high-rate of subsidence between Late Langhian to Early Tortonian (Late Badenian to Early Pannonian) (Crînganu and Deming, 1996). The tectonic mechanisms governing the basin's subsidence are not yet well understood, however several models were constructed (Royden, 1988; Gîrbacea, 1997; Ciulavu, 1999; Huismans, 1999; Sanders, 1999).

There are several well-known volcanic tuff horizons in the Badenian-Pannonian sedimentary fill of the Transylvanian Basin (Mârza and Mészáros, 1991; Pécskay et al., 1995). The chemical character of these tuffs shifts progressively from rhyolitic (Badenian) to dacitic (Sarmatian) and finally andesitic (Pannonian). The tuffs were produced by the Neogene calcalkaline subduction-related magmatic activity of the Carpathians and Apuseni Mountains.

\section{Materials and methods}

Seismic profiles, well logs, cores and outcrop samples were used as primary data for our study. The seismic profiles and well logs were interpreted on workstations.

The sequence stratigraphic model relied on the methodology and terminology of Vail et al. (1977), Vail (1987), Posamentier and Vail (1988), and Van Wagooner et al. (1988). The well logs were interpreted using methodology of Van Wagooner et al. (1990).

The sedimentologic observations on cores and outcrops were correlated and calibrated by using the micropaleontological data. The micropaleontological samples were processed and studied by standard methods, using a $63 \mu \mathrm{m}$ sieve and a scanning electron microscope. Priority was given to morphogroups because of their affinities to different paleoenvironments.

\section{Sequence stratigraphy}

Several stratigraphic sequences could be separated within the Middle Miocene (Badenian) to Upper Miocene sedimentary record, based on the sedimentologic, stratigraphic and micropaleontologic data (Table 1). Initials of Middle to Late Miocene (MLM) interval and numbering were used for sequence abbreviation. Several higher order relative sea level changes could have been interpreted, based on well log interpretation. However, at this stage we will consider only the $3^{\text {rd }}$ order regional cycles.

\subsection{Sequences MLM1 to MLM3 (latest Early Miocene to Mid-Badenian)}

During the late Early Miocene, the sedimentation, represented by coarse-grained fandeltas, was restricted only to the northern half of the basin (retro-foreland). The rest of the basin represented a continental erosional domain. Several deep (100-200 m) incised valleys (?) can be recognized based on seismic interpretation, filled by Lower to Middle Badenian sediments. We interpret the uppermost Lower Miocene sediments as belonging to the lowstand systems tract (LST1). 
Regional, but low rate of subsidence occurred during the early Middle Miocene (Early Badenian). The transgressive character of these sediments, overlaying various older sedimentary units, was recognized long time ago (Koch, 1900). The transgression was synchronous in the Alpine-Carpathian intra-mountain basins (e.g., Vienna, Pannonian, East Slovakian, etc.), reflecting major tectonic and paleogeographic changes in the entire Paratethys (Báldi, 1980; Kováč et al., 1998, 1999, 2001; Steininger and Wessely, 2000).

Deep-sea environments are known in the central and eastern part of the basin, characterized by clastic turbidites and pelagic deposition. Several volcanic tuff horizons (e.g., Dej Tuff Complex - Moisescu and Popescu, 1967) found in the Lower Badenian succession are proofs of intense volcanic activity (Seghedi and Szakács, 1991). Carbonate and clastic sedimentation dominated shallow ramp environments mainly in the western part of the basin (Hosu and Filipescu, 1996; Filipescu, 1996) - Fig. 2.

The seismic interpretation of the Lower Badenian is very difficult due to the thin, usually not more than $100 \mathrm{~m}$, sedimentary succession. Moreover, the interpretation is obstructed by several thin, closely spaced packages with high seismic impedance contrasts, sometimes combined into a single reflection. The seismic impedance changes at the transition between the salt (Middle Badenian), siliciclastics (Lower Badenian), and thick volcanic tuffs usually resting on an important stratigraphic unconformity (Dej Tuff, lowermost Badenian). the well-log data is too sparse to attempt regional correlation and interpretation. Therefore, sequence stratigraphic interpretation is mainly based on outcrop data, backed up by sedimentary facies interpretation in well logs.

Data on sequence stratigraphy of the Lower Badenian deposits were published by Hosu and Filipescu (1996) and Filipescu and Gîrbacea (1997), referring to Lower Badenian successions outcropping in the western part of the basin. The sedimentary succession consists of parasequences formed by fining upward siliciclastics (transgressive and early highstand systems tracts) followed by coarsening upward dominantly carbonate sediments (late highstand systems tracts).

On the north-western border of the basin, the initiation of transgressive conditions (TST1) can be documented by a very important planktonic bloom (foraminiferal Praeorbulina glomerosa Biozone - M5a). The fine siliciclastic (pelagic) deposits preserve the sedimentary pattern during the following planktonic invasion (TST2), as well. Due to the condensed sedimentation, in order to separate the first two sequences, the microfaunal behaviour and the correlation with the global cycles were used. The transgressive phase of the second sequence can be well documented by the planktonic bloom of the Orbulina suturalis Biozone (M5b).

Outcrop data at the border of the basin show that benthic foraminifera colonized the substrate progressively at the transition between the transgressive (TST2) and highstand systems tract (HST2). Foraminifera belong mainly to the "upper lagenide zone" (Papp and Turnovsky, 1953) (Plate 1), characterized by elongate-flattened and tapered morphogroups, which show affinities to offshore and shoreface siliciclastic and carbonate environments. Although Hosu and Filipescu (1996) separated two distinct sequences for this interval, we have to reconsider that hypothesis, because of no consistent evidence on significant basinward shift of facies belts or subaerial erosion. The initially considered lowstand systems tract at the boundary between the two sequences in the Gârbova Formation, represents in fact the late highstand systems tract facies with shoreface to nearshore sediments.

The uppermost facies of the Lower Badenian, mainly with a carbonate sedimentation, indicate progressively shallower facies, ending into the lowstand conditions of the third sequence (LST3). Shallower facies of the late highstand and lowstand systems tracts was dominated by plano-convex and rounded-planispiral foraminifera morphogroups, having a test morphology which offered a better stability and attachment possibilities.

Following the lowstand conditions, widespread but only a few meters thick pelagics were deposited. They indicate an important early Mid Badenian transgressive (TST3) event (Filipescu, 2001). The accelerated deepening of the basin at the Early-Middle Badenian boundary (also documented by microfauna) led to a high rate of relative sea level rise and started the fine 
sedimentation in the deep areas of the basin, which continued during the subsequent highstand (HST3), as well. Foraminiferal assemblages with planktonics (Globoturborotalita druryiGlobigerinopsis grilli Biozone) and tapered benthics (ornamented Uvigerina) - Plate 2, Figs. 10-13 - suggest deeper environments compared to the Early Badenian.

\subsection{Sequence MLM4 (late Mid-Badenian-Late Badenian)}

\subsubsection{The lowstand systems tract (LST4)}

- age: late Mid Badenian;

- lithology: evaporites (gypsum and salt);

- environments: sabkha to shallow ramp gypsum, deep ramp salt;

- biostratigraphy: microfauna is absent.

A relative sea level fall induced progressive restriction of the circulation in the basin, leading to brine formation, and massive deposition of salt (Koch, 1900) in the deep areas, while in the marginal areas gypsum was deposited (Ghergari et al., 1991). The gypsum beds are a few tens of meters thick, and outcrop at the western border of the basin. The salt was originally deposited in a few hundreds of meters (300?) thick successions, but their present distribution and thickness was controlled by post-depositional salt-tectonics. The salt outcrops follow two major, roughly northsouth oriented, lineaments situated near the western and eastern borders of the Transylvanian Depression (Ciupagea et al., 1970). They were produced by the salt extrusions related to the late Mid-Miocene (Late Sarmatian) to Pliocene thrust systems (western part of the basin), and Pliocene gravitational gliding processes (eastern part of the basin) (Krézsek, 2004).

The gypsum was deposited in sabkha-type to shallow-water evaporitic environments. The ramp areas were located mainly at the western part of the basin. Deeper, evaporitic environments characterized the inner and eastern part of the basin, where only salt deposits are known. No outcrops with significant interbeddings of different evaporitic facies have been observed so far. Only in a few wells drilled at the western part of the basin (e.g., 4205 Copand), the gypsum beds are overlayed by the salt (Dragoş, 1969), or are deposited above the salt, interbedded with offshore sediments.

The evaporites were deposited in a tectonically stable basin, with a constant subsidence rate, represented by a deep facies. Some deep wells drilled through the salt formation (e.g., 1 Sânmiclăuş) encountered several fine epiclastic intercalations, some of them several meters thick. These represent hemipelagic sediments transported in the restricted, evaporitic basin by marine ingressions, that might be related to tectonic and/or climatic changes. The top level of brine in the evaporitic basins was below the contemporaneous open sea level (Peryt, 2001); therefore small scale sea-level fluctuations triggered rapid floodings of the basin. This was probably generated by subsidence rate changes related to the Carpathian compressional movements, which interfered with the larger scale trend of sea-level fall (Popescu and Brotea, 1994).

The evaporitic environments were very similar to the facies of the Carpathian foredeep, described in southern Poland (Kasprzyk and Orti, 1998; Peryt, 2002; Cendón et al., 2004) or western Ukraine (Peryt, 2001). In the Pannonian Basin, the "Middle Badenian sea-level fall" (Báldi, 1980) correspond to erosion and hiatus (Tari, 1994; Vakarcs et al., 1994; Horváth, 1995; Báldi et al., 2002).

\subsubsection{The transgressive systems tract (TST4)}

- age: early Late Badenian;

- lithology: anoxic to dysoxic shales, thin sandstones;

- sedimentology: condensation, pelagics and thin turbidite complexes;

- environments: outer ramp to deep marine (hundreds of meters);

- biostratigraphy: lower Velapertina Biozone. 
Tectonic shortening in the Eastern Carpathians (Săndulescu, 1988; De Broucker et al., 1998; Ciulavu, 1999), increased the subsidence rates of the Transylvanian Basin. The accelerated subsidence increased the rate of creation of accommodation space and ended the evaporitic sedimentation. This was recorded as a marine flooding event (Popescu, 1972; Dumitrică et al., 1975) - TST4 - also indicating the establishment of large seaways towards the Eastern Paratethys.

The Upper Badenian deposits are almost exclusively represented by clastic turbidites and pelagics. Their thickness range from a few hundred of meters $(\sim 500)$ in the western part of the basin up to $1000-2000 \mathrm{~m}$ in the east. The lower part of the Upper Badenian succession is represented by shales interbedded with thin turbidite complexes. The organic content of the shales indicate dominant anoxic to dysoxic, relatively deep (hundreds of meters), environments.

The seismic facies of the Upper Badenian is characteristic for deep basin environments (Mitchum et al., 1977; Mitchum, 1985; Mutti and Normark, 1991), dominated by continuous, low to moderate amplitude reflectors (Fig. 3). The calibrated log facies (SP and Resistivity; Figs. 3 and 4) correspond to stacked mid to distal fan lobes (Mutti, 1992). There are no clearly channeled deposits in the lower Upper Badenian (in contrast to the Sarmatian, where the chanelled deposits are very common).

Based on outcrop and core sedimentology, log and seismic facies interpretation, and micropaleontologic data, the lower Upper Badenian sediments belong to mud and mud-sand dominated (Reading and Richards, 1994), high efficiency submarine fan systems (Mutti, 1985). The log data show an overall fining-upward stacking pattern of the submarine fan lobes (Fig. 4) for the lowermost Upper Badenian. The submarine fans onlapped submarine basinal heights, which became sites of condensed sedimentation (Fig. 5).

The deep marine setting is suggested by almost exclusive planktonic assemblages with diatoms, radiolarians, silicoflagellates, planktonic foraminifera (Velapertina Biozone) and pteropods (Plate 3, Figs. 1-3). By the time the sea-level reached its maximum, the lack of vertical water circulation produced anoxic bottom environments, improper for the benthic life.

\subsubsection{The highstand systems tract (HST4)}

- age: middle Late Badenian;

- lithology: sandstone and marl;

- sedimentology: prograding submarine fans and pelagics;

- environment: outer ramp to deep marine (hundreds of meters);

- biostratigraphy: Velapertina Biozone, Bogdanowiczia pocutica Subzone.

Well-log facies of the Upper Badenian indicate only deep submarine environments for the upper part of the stage, same as for its lower part. However, in contrast to these, the upper stacked submarine fans have an overall coarsening-upward log trend (Fig. 4). They belong to mud-sand to sand dominated (Reading and Richards, 1994), moderate to low efficiency submarine fan systems (Mutti, 1985). The progradation of the submarine fans is related to the Upper Badenian highstand systems tract.

The foraminiferal assemblages are very useful in dating the start of progradation process. This is because of the first occurrence of agglutinated benthic foraminifera assemblages (Bogdanowiczia pocutica - Plate 3, Fig. 4), after the net dominance of planktonics (TST4). We consider this event to be related to the initiation of sedimentary lobes progradation, which triggered the bottom water circulation, as well (Filipescu, 2004a).

It is difficult to interpret the sequence stratigraphy of the uppermost Badenian sediments, because of unavailable data at the borders of the basin. It is also very difficult to confidently interpret the submarine fans' paleoflow directions, both because of the very rare dipmeter data in the Transylvanian wells, and the lack of outcrops. However, based on a few dipmeter log measurements and lithology of stacked submarine fans, we suspect mainly two sources: western part of the Southern Carpathians and north-eastern (Rodnei Mountains area). The area of present Perşani Mountains (south-eastern corner of the basin) represented the deepest part of the 
Transylvanian Basin, which, at least through the Braşov passage (bending area of the Carpathians), had wide open marine connections with the foreland area (Tărăpoancă, 2004).

Interpretation of regional seismic profiles indicates that the Upper Badenian sedimentary succession becomes thicker toward the Eastern Carpathians (Fig. 5), but showing well developed onlaps on the salt layer toward the western and north-western areas. Some authors (De Broucker et al., 1998; Ciulavu, 1999) interpreted it as a result of a Middle Badenian tectonic tilting of the basin basement, which created an unconformity on the top of the salt layer. However, there are no sedimentary or paleontological proofs for this "sudden" tectonic change (e.g., continental deposits or

littoral progradation). Besides, in the "uplifted" northern and western part of the Transylvanian Basin, we found mainly condensed sedimentary successions with small distal to outer fan lobes above the salt, which means that these areas experienced starved basin conditions during the Late Badenian. This interpretation is well documented by the micropaleontological data, as well. We propose a different tectonic model for the Upper Badenian sedimentary architecture (Fig. 6). Due to the asymmetrical basin subsidence, the submarine fans were trapped mainly in the inner to eastern part of the

basin, while the western part and the Apuseni Mountains area functioned as a starved basin. The asymmetric subsidence rates, generated by progressive Late Badenian tectonic tilting of the basin's basement toward the Carpathian orogen, were also enhanced by the sedimentary load. Upper Badenian onlaps found on the salt (Fig. 5) are not coastal onlaps, but deep-marine. Their west- and northwestward onlapping character indicate westward thinning of the submarine fans, while passing from proximal to distal and finally to condensed intervals. Therefore the successive, westward and north-westward onlapping seismic horizons represent prograding sub-marine fan systems toward the starved western and northwestern area of the basin.

\subsection{Sequence MLM5 (latest Badenian-mid Early Sarmatian)}

\subsubsection{The lowstand systems tract (LST5)}

- age: latest Badenian;

- lithology: sandstone, conglomerate;

- sedimentology: prograding ramp, lowstand submarine fans;

- environment: proximal ramp and deep marine (hundreds of meters);

- biostratigraphy: Velapertina Biozone.

Increased regional compressional stress by the end of Badenian (Săndulescu, 1984) led to a partial closing of the earlier established marine seaways, and relative sea-level fall. These events were reflected in the Transylvanian Basin by high sediment input, prograding shallow-marine systems and progressive restriction of the connections to the open-seas. Ramp settings during the latest Badenian (LST5) have been deduced upon the evidence of Borelis-type faunas, also mentioned by Popescu (1979). It has to be noticed that shallow marine faunas can be found in wells drilled in the southern and south-eastern part of the Transylvanian Basin (Saschiz-NetuşBărcut area, Ilimbav-Chirpăr). These areas represented submarine heights during the Late Badenian, separating different deeper troughs. Relative sea-level fall during the latest Badenian established shallow-water conditions on the existing submarine heights, while other, deeper areas were sites of coarse-grained lowstand submarine fan deposition. Submarine channels were incised into the previous highstand slope turbidites in the northern area (Fig. 7). The base of this lowstand systems tract represents a regional sequence boundary (SB5), which marks the end of the MLM4 sequence. We consider that these sediments were deposited during the lowstand, based on:

- highly erosional character of the coarse grained submarine fans, and

- sudden overlaying of deeper marine facies by littoral and shallow ramp facies. 
One of the major factors influencing the sedimentary processes subsequent to Late Badenian was the salt tectonics. Salt migration was already active during the latest Badenian, controlled by the mutual interaction between sedimentary load and the position of submarine fan depocenters. Therefore, the Upper Badenian submarine fan depocenters turned to be active salt evacuation areas. The migration process led to incipient diapir (or salt pillow) development and contributed to the channeling of submarine fans between these salt-related heights. At a large scale, the Latest Badenian to Sarmatian submarine fans are rather stacked between the salt-related heights, than spread across on an "open and wide" basin floor.

\subsubsection{The transgressive systems tract (TST5)}

- age: latest Badenian (?)-earliest Sarmatian;

- lithology: marl, rare sandstones;

- sedimentology: condensation, rare and thin submarine fans;

- environment: outer ramp and deep marine (hundreds of meters);

- biostratigraphy: Anomalinoides dividens Biozone.

Sarmatian times were characterized by a high tectonic instability: beginning of the "continent-continent" collision in the Eastern Carpathians (Horváth and Cloetingh, 1996; Sanders, 1999), overall compressional regime (Ciulavu, 1999), rapid subsidence (Balintoni et al., 1998; Sanders, 1999), and accelerated sedimentation rates (Crînganu and Deming, 1996).

The Sarmatian was characterized by diverse salinity conditions, stretching from brackish to hypersaline (Filipescu et al., 2000). Endemic faunas populated the restricted marine environments; therefore, from this level up, direct biostratigraphic correlations with the Mediterranean realm are difficult.

The transgressive character (TST5) of the lowermost Sarmatian deposits (Anomalinoides dividens Biozone) was described long time ago (Koch, 1900). The Lower Sarmatian marls overlay various older sedimentary and crystalline units. However, some well data (Fig. 4) suggest that the transgression initiated close to the end of Badenian. The Badenian/Sarmatian faunal change occurred

during the transgression, reflecting progressive water chemistry changes. Because of the restricted communication with the open seas, the very few remaining Late Badenian planctonic faunas (small Globigerina) were rapidly replaced by opportunistic endemic species such as Anomalinoides dividens (Plate 3, Fig. 5), with a possible pseudo-planktonic behaviour (Filipescu, 2004b).

\subsubsection{The highstand systems tract (HST5)}

- age: Early Sarmatian;

- lithology: sandstones, marls;

- sedimentology: pelagics and prograding submarine fans;

- environment: outer ramp and deep marine (hundreds of meters);

- biostratigraphy: Anomalinoides dividens Biozone.

Highstand systems tract conditions (HST5), following the transgressive event at the base of Sarmatian (condensed sedimentation), are suggested by the diversification of the benthic assemblages. In deep basin settings, characterized by condensed sedimentation during the previous transgressive systems tract (TST5), prograding submarine fans were deposited. Brackish faunas and reworking processes occur together with prograding sedimentary lobes.

\subsection{Sequence MLM6 (late Early Sarmatian)}

\subsubsection{The lowstand systems tract (LST6)}

- age: late Early Sarmatian;

- lithology: sandstones, marls, evaporites;

- sedimentology: delta, lowstand submarine fans, incised submarine valleys; 
- environment: proximal ramp to deep marine (hundreds of meters);

- biostratigraphy: Varidentella reussi Biozone.

Hypersaline conditions are common for what we interpreted as the lowstand of the following sequence (LST6). Miliolids of the Varidentella reussi Biozone and thin gypsum beds suggest such an environmental setting. The relative sea-level fall produced large-scale erosion (Fig. 8) in the northern part of the basin (submarine channels incised slope deposits).

\subsubsection{The transgressive and highstand systems tracts (TST6-HST6)}

- age: late Early Sarmatian to early;

- lithology: marls, sandstones;

- sedimentology: delta, outer ramp, submarine fan;

- environment: shallow ramp and deep marine (hundreds of meters);

- biostratigraphy: Elphidium reginum and partially Dogielina sarmatica biozones.

The foraminiferal re-diversification (elphids, nonionids - Plate 3, Figs. 6, 8, 10) shows a facies deepening associated to a transgressive event (TST6, Fig. 8). During the subsequent highstand (HST6, Fig. 9) large scale sandy deltaic progradation occurred in the northern part of the Transylvanian Basin. Mysids (Plate 3, Fig. 9) and reworked foraminifera are very characteristic along the whole interval with prograding submarine lobes.

The deltaic depocenters progressively passed southwards until the Late Sarmatian, while coarse-grained fandeltas prograded at the eastern part of the basin. Large amount of siliciclastic sediments were transported and deposited as submarine fans in the deep areas (e.g., Târnave area).

Because of the south-eastward post-Pannonian basin tilting and active salt-tectonic movements, shallow water deposits are mainly preserved in the eastern part of the basin. The interplay of salt tectonics and sedimentation was responsible for the formation and filling of relatively deep-marine troughs related to salt-withdrawal and compressional tectonics (Fig. 9). Several higher order sequence boundaries were observed in the eastern part of the basin (Fig. 9), which correspond to major episodes of turbidite sand deposition (lowstand fans) and important salt-tectonic movements.

The deep-water turbidite sands were systematically channeled and stacked in deeper areas controlled by the salt movement.

\subsection{Sequence MLM7 (latest Sarmatian-Early Pannonian)}

\subsubsection{The lowstand systems tract (LST7)}

- age: Late Sarmatian;

- lithology: sandstones;

- sedimentology: delta, fandelta, lowstand submarine fans, incised valleys.

- environment: shallow ramp and deep marine (hundreds of meters);

- biostratigraphy: partially Dogielina sarmatica Biozone.

By Late Sarmatian, the end of the subduction (Săndulescu, 1984; Sanders, 1999; Huismans, 1999) was accompanied by a regional uplift of the Transylvanian Basin borderlands, together with the Carpathians. This was one of the most important rising moments of the Apuseni Mountains, which did not represent an important sediment source for the basin until that time. It was also reflected in the basin as one of the major tectonic events, deeply influencing the salt-tectonics: several salt-related structures of the basin were reactivated, and some of them inverted (turtle structures).

Sandstones were deposited in a shallow ramp setting in the western part of the basin. They unconformably overlay earlier outer shelf marls. Coarse-grained fandeltas were actively prograding in the east. Incised valleys are common, cut in the previous deltaic to outer ramp deposits. The coarse-grained fandeltas fed lowstand prograding submarine fans in the center of the basin. 
Increased salt-tectonics activity generated several turtle structures in the eastern part of the basin. The structural inversions enhanced submarine erosion and channeled the submarine fans. A large-scale submarine unconformity is shown in Fig. 9, related to the lowstand conditions at the end of the Sarmatian.

\subsubsection{The transgressive systems tract (TST7)}

- age: latest Sarmatian-earliest Pannonian;

- lithology: marls, sandstones;

- sedimentology: shallow ramp, deep marine to (?) lacustrine condensation;

- environment: shallow ramp and deep marine to (?) lacustrine (hundreds of meters);

- biostratigraphy: Porosononion aragviensis Biozone.

A progressive deepening of the basin occurred by the end of Sarmatian. Seismic interpretation indicate that sediments onlap the previous lowstand systems tract (Fig. 9), forming a large-scale retrogradational geometry (TST7). As a consequence, the microfauna diversified again within the Porosononion aragviensis Biozone, where evolved species of Porosononion and Elphidium (Filipescu, 1999) are dominant (Plate 3, Fig. 12). Deep shelf assemblages with Bolivina sarmatica (Plate 3, Fig. 11) are also common for this interval.

The Carpathian tectogenesis at the end of Sarmatian lead to the isolation of the central and eastern Paratethyan areas, creating conditions for spectacular development of the Lake Pannon's endemic fauna (Magyar et al., 1999b; Müller et al., 1999).

The occurrence of Pannonian fauna in the Transylvanian Basin is related to a strong transgressive event, recorded by outer-ramp marls deposited on the top of the Upper Sarmatian fandeltas or submarine fans. Lower Pannonian sediments indicate mainly condensed sedimentation. Consequently, the microfaunal changes followed a particular trend across the Sarmatian-Pannonian

boundary. The change of water salinity, caused by the interference with the tectonic uplift (increased

fresh-water input in a restricted environment), produced the extinction of the foraminiferal faunas. The rare Miliammina subvelatina specimens are the only proofs for the presence of opportunistic foraminifera during the Early Pannonian. They were replaced by ostracod faunas (Wanek, 1992) Plate 3, Figs. 13-15 - better adapted to the particular salinity conditions. Although the faunal change progressively occurred during the transgression, typical Pannonian faunas are present only in the upper transgressive systems tract.

\subsubsection{The highstand systems tract (HST7)}

- age: Early Pannonian;

- lithology: sandstones, marls, rare fine conglomerates;

- sedimentology: ramp marls and sandstones, lacustrine fans;

- environment: fandelta, ramp and deep lacustrine (hundreds of meters);

Following the transgression in the eastern Transylvanian Basin, prograding deltaic successions were recognized (Krézsek, 2005). They contain small-scale prograding cycles (Gräf et al., 1973; Krézsek, 2005). The shallow marine succession is no more then $200 \mathrm{~m}$ thick, and is mainly built by cross-stratified sandstones and conglomerates. They overlay lowermost outer ramp Pannonian marls, which indicate widespread condensation. The microfauna is exclusively represented by ostracods (Wanek, 1992). In the deep lacustrine environments sand to mud dominated prograding submarine fans systems were deposited (Krézsek, 2005).

\subsection{Sequence MLM8 (mid Early Pannonian-Late Early Pannonian?)}

\subsubsection{The lowstand systems tract (LST8)}


- age: mid Early Pannonian?;

- lithology: conglomerates and sandstones;

- sedimentology: lowstand fandelta, proximal lacustrine fan, incised lacustrine fan channels;

- environment: continental?, shallow ramp, deep lacustrine (hundreds of meters).

Relative sea level fall during the mid Early Pannonian induced coarse grained fandelta and related submarine fan system progradation in the eastern Transylvanian Basin (Krézsek, 2001, 2005). The fandeltas were fed by amalgamated alluvial fan systems (Krézsek, 2005).

\subsubsection{The transgressive and highstand systems tract (TST8-HST8)}

- age: late Early Pannonian?;

- lithology: marls, sandstones;

- sedimentology: outer ramp, sandy fandelta and delta, lacustrine fan;

- environment: shallow ramp, deep lacustrine (hundreds of meters).

The transgressive (TST8) and highstand (HST8) systems tracts were interpreted only in a few restricted areas in the eastern part of the basin, based on outcrop sedimentology. A large scale coarsening-upward sedimentary succession, from distal shelf deposits to fandelta sediments can be observed (Krézsek, 2005). The marine maximum flooding (mfs8) seems to be related to the reestablishment, for a very short time, of the connections with the extra Carpathian regions. This is supported by a very interesting foraminifera level also (Ammonia acme), found mainly in the eastern Transylvanian Basin. These would argue for the existence of low relief corridors in some parts of the Eastern Carpathians during the Earliest Pannonian, which would have been overflooded by an extrabasinal relative sealevel rise.

The vast majority of the outcropping Pannonian deposits belong to lacustrine fans. Probably the youngest Pannonian (early Late Pannonian?) deposits are preserved in littoral sands (HST8?) at Vingard (Lubenescu, 1981) and Sâncrai (Wanek, pers. com). Shallow-water to continental Pannonian facies was commonly covered by the Pliocene volcanic products of the Eastern Carpathians (Pécskay et al., 1995).

The Pliocene to Holocene evolution of the Transylvanian Basin was characterized by a strong uplift and erosion (Sanders, 1999). In general, the upper part of the basin fill (Late Pannonian and younger?) was removed from the regions not covered by the Eastern Carpathians' volcanics. Where existing (sediments younger than 9 M.a.), they are covered by the Pliocene volcanic products.

\section{Discussion}

The Middle to Late Miocene Transylvanian Basin's evolution is strongly related to the Carpathians' tectonic history. Based on subsidence patterns and sedimentology, the basin's evolution can be divided into four major phases: 1. early Mid-Miocene (Early and Mid Badenian); 2. middle Mid-Miocene (Late Badenian to Early Sarmatian); 3. latest Mid-Miocene to early Late Miocene (Late Sarmatian to Pannonian); 4. Late Miocene to Recent (post-Pannonian).

\subsection{Early Mid-Miocene (Early to Mid-Badenian): TST1-LST4}

During the Early Miocene, the sedimentation was primary controlled by the thrusting of the Pienides system (Săndulescu, 1984, 1988), which generated the down-bending of the northern Transylvanian Basin's basement and created a high-rate subsiding area (De Broucker et al., 1998; Ciulavu, 1999). This late Early Miocene basin can be regarded as a flexural basin, filled by mainly coarse-grained sediments supplied by fandeltas. A flexural bulge located roughly in the middle part of the basin separated this high-rate subsiding area by the southern Transylvanian Basin. The 
flexural bulge restricted the sedimentation to the northern area of the basin, while in the south erosion was active.

At the beginning of the early Mid-Miocene (Early Badenian) the marine sedimentation extended to the southern Transylvanian Basin also. This event corresponds to major tectonic, ecologic, and sedimentary changes. In the Pannonian Basin, this major change represents the beginning of the first active rifting phase, while large scale extension - transtension was documented through seismic and microtectonic analysis (Tari, 1994; Csontos, 1995; Bada, 1999; Fodor et al., 1999).

The Mid-Miocene (Early Badenian) tectonics of the Transylvanian Basin is a controversial topic. Several contrasting data have been published. Huismans et al. (1997), Huismans (1999), and Ciulavu (1999) support the existence of a small scale, east-west oriented, early Mid-Miocene tensional phase in the Transylvanian Basin. However, no major regional faults have been identified so far. In addition, microtectonic data in the area of North Transylvanian Fault indicate a Middle Miocene compressive strike-slip (Tischler, pers. com.).

Compressional wrenching (De Broucker et al., 1998) is also visible on seismic sections, such as several, small-scale strike-slip faults cross-cut the Early Miocene sedimentary wedge in the northern part of the basin (De Broucker et al., 1998; Ciulavu, 1999). These faults are early MidMiocene (Early Badenian) in age, because they cut the Lower Miocene deposits and are sealed by the Middle Miocene (Middle Badenian) salt. The small scale strike-slip faulting might be related to the onset of the clockwise rotation of the Transylvanian Basin, although the major rotation stage is Late Badenian to Sarmatian (Pătraşcu et al., 1994; Panaiotu, 1998). The presence of an extensional/transtensional stress field cannot be ruled out, but it is unlikely that this can be solely responsible for the basin regional subsidence.

The MLM1 to MLM4 sequences were formed during this stage. Slow-rate of subsidence and warm climate supported the carbonate deposition. Several clastic sources may have been existed also, as indicated by mixed siliciclastic-carbonatic shallow-marine deposits. In general, the shallow-marine ramp-type environments prevailed. The presence of carbonates indicates favorable conditions for the carbonate factory, and the siliciclastic material point to spread of the clastic material along the shoreline by drift currents. In deeper ramp setting mainly hemipelagic sedimentation prevailed.

One of the debated topics of the basin's evolution is the change from evaporitic (LST4) to siliciclastic sedimentation (TST4). In the Transylvanian Basin, several onlapping reflectors are visible on the seismic sections, which suggest a large-scale transgression following the salt deposition. The salt deposition was interpreted as representing the lowstand systems tract (LST4, see above) triggered by a regional relative sea level fall, observed through the whole Central Paratethys. In the extensional back-arc type Pannonian Basin, erosion occurred because of the elevated position of its central part due to the active rifting (updoming).

The Carpathians' foreland basins and a few "peripheral" backarc basins (relative to the central Pannonian Basin, as the Slovakian and the Transylvanian basins), functioned as interconnected evaporite basins. Relative sea level rise at the beginning of the Late Badenian triggered progressive shift from hypersaline (brine) to anoxic conditions. The restricted conditions are indicated by the sedimentary succession, dominated by laminated, black shales. They represent one of the most important hydrocarbons source rocks in the basin. The waters were highly stratified in the basin, therefore only the planktonic organisms were able to survive and only in the uppermost water body. This can explain the lack of any benthic fauna during the transgression. The micropaleontological content of the early Late Badenian sediments clearly indicates deepmarine environments. This is a strong evidence for interpreting the onlaps as marine onlaps (see also at TST4). Another evidence is that the salt deposits are underlain and overlain by pelitic deposits with only planktonic assemblages, indicating that the salt deposition produced in deep environments during a regional desiccation event. 
Comparing the identified relative sea-level changes with the global sea-level curves (Table 1), we might conclude that the observed trends fit well with the global cycles, but there are also important differences, which may be related to tectonic factors. Therefore, our sequences are mainly eustatically driven, with occasional tectonic overprint.

\subsection{Middle Mid-Miocene (Late Badenian to Early Sarmatian): TST4-HST5}

The tectonic regimes of the Middle to Late Miocene in the Transylvanian Basin indicate an overall west to east or northeast to southwest oriented compressional stress field (Ciulavu, 1999; Huismans, 1999). The compression was related to the beginning of the final collision between the Tisa-Dacia unit and the East European Platform (Săndulescu, 1984, 1988), which triggered the progressive uplift of the Carpathians (Sanders, 1999) and the emplacement of latest Outer Carpathian nappes (Mațenco, 1997; Zweigel, 1997).

Middle to Late Miocene compressional structures are widespread in the basin, and are also indicated by microtectonic (Ciulavu, 1999; Huismans, 1999) and seismic data (De Broucker et al., 1998; Ciulavu, 1999; our data). However, most faults stop in the salt-layer, indicating that the salt represented a major decoupling horizon, between the pre-salt and post-salt succession.

The Late Badenian to Sarmatian was the time of major clockwise rotation of the Transylvanian Basin, as indicated by paleomagnetic measurements (Pătraşcu et al., 1994; Panaiotu, 1998), however, it is worth to be mentioned that based on seismic interpretation, most of the major strike-slip faulting occurred during the early Mid-Miocene (Early Badenian). The regional compression generated a high rate of subsidence of the Transylvanian Basin during the late Mid to Late Miocene. There are at least three mechanisms of subsidence proposed: roll-back of the subducted plate and various associated processes (Royden, 1988; Gîrbacea, 1997; Huismans, 1999), sag basin (Tari et al., 1999) and retro-foreland (Sanders, 1999). Regardless of the proposed mechanisms, at that time the basin subsidence was very high, several times higher than during the early Mid-Miocene, or during the whole Mid-Miocene of the Pannonian Basin. This is because in the Pannonian Basin the active rifting related astenospheric rise and updoming is still an ongoing process, preventing high rate of subsidence. In turn, the Pannonian basin encountered high-rate of subsidence only during Late Miocene (Pannonian), in the passive rifting phase of the backarc extension.

During the middle Mid-Miocene (Late Badenian to Early Sarmatian) the Transylvanian Basin remained underfilled and deep-marine environments prevailed. The sedimentary input was relatively high, but not high enough to keep up with the high subsidence rates. Therefore, it is important to emphasize that, during the MLM4 to MLM5 sequences, shallow water facies is only known from the latest Badenian LST6 (Table 1), while the whole basin was a site of deep-marine sedimentation (Fig. 6). The border zones of the basin during the Late Badenian to Early Sarmatian were well beyond the present borders. In fact, during the Late Badenian the only elevated areas were represented by the northern part of the Eastern Carpathians and the westernmost part of the Southern Carpathians, while most of the present Carpathians, Apuseni Mountains and the eastern Pannonian Basin were flooded, with only small patches of ridges elevated. However, these sites of shallow water sedimentation were not preserved because of the Late Miocene to Quaternary upliftrelated erosion of the Carpathians (Sanders, 1999).

Paleogeographic reconstructions of the Carpathian foreland basin (Tărăpoancă, 2004) suggest direct connections with the Transylvanian Basin also. The highest subsiding area of the Transylvanian

Basin probably was situated near the present bend of the Carpathians.

\subsection{Latest Mid-Miocene to early Late Miocene (Late Sarmatian to Pannonian): LST6-HST8}


The tectonic compression reached to the climax during the Late Sarmatian, as a result of "continent to continent" collision between the "Transylvanian block" and East European continental plate (Săndulescu, 1988). The Carpathian's accretionary wedge was progressively uplifted, triggering restriction of the marine connections between the intra-Carpathian area and the Eastern Paratethys. The intra-Carpathian area became isolated only during the Late Miocene, when it was transformed to a large brackish (?) to fresh-water lake, called the Lake Pannon (Magyar et al., 1999a). During the Pannonian, this huge lake covered not only the Pannonian basin, but also the Vienna, Slovakian and Transylvanian basins. These "marginal" basins, situated in the neighborhood of the uplifting Carpathians, were filled until the Pontian (Magyar et al., 1999a), because of high rate of sedimentary input from the Carpathians.

The Late Sarmatian Carpathians' uplift is well reflected in the Transylvanian Basin's sedimentary record. While the lowermost Sarmatian is mainly pelitic, with a relatively small amount of sands, the Upper Lower Sarmatian to Pannonian is sandier (deep-marine facies; lowefficiency submarine fans) and/or conglomeratic (the shallow-marine facies). During the Upper Sarmatian because of the active progradation of the coarse grained deltaic and fandeltaic systems the shallow-marine facies belt prograded toward the inner part of the basin. The fandeltaic systems fed low efficiency submarine-systems in the basin center. All together indicate the increase of sediment input and tectonic instability during the Late Sarmatian.

The main salt-tectonic movements are recorded during the Late Sarmatian, activated by increased compressional stress and also by the sedimentary loading. Several turtle structures formed in the eastern part of the basin. Salt-withdrawal created several "minibasins" (i.e., a few kilometer wide, local sunk areas on the Upper Sarmatian basin slope), which trapped the gravitational flows running toward the basin center. Sedimentary loading of the submarine fans and deltaic systems enhanced the compressional tectonics and triggered salt migration.

As part of the Lake Pannon, the Transylvanian Basin represented an isolated basin during the Late Miocene, as indicated by the endemic faunas (Müller et al., 1999) Therefore, the eustatic factor governing relative sea-level changes can be ruled out. Small-scale relative sea-level changes triggered by Milankovich-type orbital forcing are known from the Pannonian Basin (Juhász et al., 1997), but major relative sea-level changes are not present. These small scale lake-level variations most probably affected the lake level in the Transylvanian Basin, even if the late Mid to Late Miocene large-scale lake level falls cannot be solely interpreted as results of orbital forcing. Therefore, in our opinion, the MLM7 and MLM8 sequences represent tectonically driven sequences.

\subsection{Late Miocene to Recent (post-Pannonian)}

Youngest Pannonian deposits preserved in the Transylvanian Basin are Late Pannonian (ex. Vingard, littoral facies, Lubenescu, 1981) or at most earliest Pontian in age (Sâncrai; shallowmarine and continental; Wanek, pers. com; Krézsek, 2005). In the eastern Transylvanian Basin, Pontian to Pliocene volcanics unconformably covers the Pannonian deposits (Szakács and Seghedi, 1995; Pécskay et al., 1995; Krézsek, 2005). Therefore, the Transylvanian Basin was filled up at least until the Pontian, although most of the late-stage sedimentary fill of the basin comprising shallow-marine to continental deposits were eroded during the Pliocene and Quaternary.

The erosion was initiated by the uplift and southeastward tilt of the Transylvanian Basin (Sanders, 1999). Fission-track analyses suggest that at least $500 \mathrm{~m}$ of sediments were eroded (Sanders, 1999).

\section{Conclusions}

Together with the particular evolution of the Transylvanian Basin, we pointed out the very good correlation potential of the geophysical, sedimentological and micropaleontological data. 
The eight distinct sequences identified in the Middle to Upper Miocene formations could be assimilated as parts of five third order global cycles - TB 2.3 to TB 2.6 and ?TB 3.1 (Haq et al., 1988)-even if their direct genetic relations of the global cycles must be treated carefully. Based on our data (Table 1), the SB3 to SB6 sequence boundaries represent tectonically enhanced sequence boundaries, while the SB7 and SB8 are clearly tectonically driven.

Our scheme (Table 1) offers an improved resolution for the stratigraphic record of the Miocene in the Transylvanian Basin. The following sequence of events could be revealed:

1. Upper Lower Miocene sediments in the Transylvanian Basin belong to the final phase of the flexural foredeep (retro-foreland?) basinal evolution. Major tectonic stress field changed near the Early/Mid-Miocene boundary and induced lowstand conditions (LST1). Continental erosional domains with large scale incised fluvial valleys prevailed in the southern part of the basin, while in the northern part the sedimentation is dominated by prograding coarse grained fandeltas.

2. At the beginning of the Mid-Miocene (Early Badenian), regional, but low rate subsidence induced flooding of the whole basin and widespread marine sedimentation (TST1). This represents the beginning Mid to Upper Miocene compressional back-arc type evolution of the Transylvanian Basin. During the Early Badenian, shallow marine clastic and carbonate ramp, and deeper marine environments were dominant. The Lower Badenian succession usually is no more than $100 \mathrm{~m}$ thick. Two sequence boundaries were recognized in the Lower Badenian based on outcrop sedimentological and micropaleontological data (Table 1). Very rich foraminifera assemblages document the Early Badenian relative sea-level trends and support the sequence stratigraphic interpretation.

3. An important transgression (TST3) produced at the start of the Mid-Badenian, followed by highstand conditions. Mainly condensed sedimentation dominated the whole basin.

4. During the late Mid-Badenian, global eustatic sea-level fall, enhanced by regional compressional tectonics, isolated the Transylvanian Basin and initiated the lowstand (LST4) sedimentation of halite and gypsum in a deep, desiccated basin.

5. At the beginning of the Late Badenian, high-rate subsidence of the basin ended the lowstand conditions and produced an important transgressive event (TST4). Dysoxic to anoxic shales (condensation) and fine sandy turbidites were deposited. They form a large scale retrogradational cycle. The assemblages consist only of planktonic groups (foraminifera, radiolarians, pteropods and diatoms).

6. Middle Late Badenian highstand conditions (HST4) are well documented by progradational sandy submarine fans. The progradation supported the substrate oxygenation and facilitated rapid colonization by deep benthic taxa.

7. Carpathian tectonic activity induced relative sea-level fall by the end of the Badenian (LST5). Shallow-water ramp to littoral sandstones unconformably overlay the Late Badenian highstand submarine heights, which previously represented sites of sedimentary condensation. Coarse grained lowstand submarine fans were deposited in deeper areas.

8. The faunal change at the Badenian/Sarmatian boundary was produced by a new transgressive event (TST5). The water chemistry changes produced the replacement of the typical marine faunas with endemic assemblages. The transgressive phase is represented by deep marine and outer ramp marls, but thin turbidite intercalations are also known. The fine sandy turbidite intercalations begin to form larger, progradational cycles during the subsequent highstand conditions (HST5), also documented by brackish benthic foraminifera.

9. Large scale relative sea-level fall, probably of tectonic origin, generated lowstand conditions (LST6) during the late Early Sarmatian. Thin evaporites and shallow water sands were deposited in ramp settings. Submarine channels incised previous highstand slope fine grained sediments, and coarse grained submarine fans were deposited in the 
deeper environments. The shallow, slightly hypersaline environments were populated by endemic faunas.

10. Lower Upper Sarmatian seismic packages show well developed clinoforms, documenting large scale deltaic progradation. Diversification and specific microfossil assemblages indicate the sea-level trends. In shallow water deltaic environments, the sedimentary succession is represented by retrogradational (TST6), followed by progradational parasequences (HST6).

11. One of the main uplift phases of the Carpathians is related to the Late Sarmatian compression. The uplift induced lowstand conditions (LST7) at the end of Sarmatian and final isolation of the Transylvanian Basin from the Eastern Paratethys. Coarse-grained littoral, shallow ramp and fandelta sandstones were dominant. Widespread continental erosion occurred at the basin margins and several submarine channels were incised in the Upper Sarmatian clinoforms.

12. The transgression at the end of Sarmatian (TST7) produced a new benthic foraminifera diversification. However, because of isolation and increased fresh water input from the uplifted mountain ranges, foraminifera were progressively pushed to extinction. In parallel, their place was taken by ostracods, a group better adapted to the new conditions, which started flourishing during the Pannonian. During the transition to highstand conditions at the beginning of Pannonian, fine sediments blanketed different older sedimentary units, including the coarse grained Upper Sarmatian fandeltas.

13. Earliest Pannonian highstand conditions (HST7) are indicated by upward-coarsening progradational cycles described in the eastern part of the basin. They are represented by outer ramp marls, with several upward thickening sandstone intercalations.

14. Mid Early Pannonian lowstand (LST8) is well documented by large scale erosion and active progradation of very coarse grained (conglomerates) fandeltas feeding sandy lacustrine fans.

15. During the late Early Pannonian transgression (TST8) and highstand (HST8), outer shelf marls and shallow water to littoral sands were deposited unconformably on the top of the lowstand fandeltas. At large scale they form a progradational cycle.

16. In general, Upper Pannonian and (?)Pontian, deposits were covered by Pliocene volcanics or were eroded because of the Pliocene uplift of the Transylvanian Basin.

17. Based on general subsidence and sedimentary patterns the Transylvanian Basin compressional back-arc evolution may be devided in four distinct evolutionary stages:

a. Early to Middle Badenian (TST1 to LST4). Subsidence rates of the basin were very low compared to the Late Badenian to Pannonian subsidence rates. The sedimentation extended from the north (Early Miocene) to the whole basin. In general, two major sedimentary environments prevailed: shallow mixed (carbonatic-siliciclastic) ramptype environments at the basin's margins and deeper (mostly neritic) siliciclastic environments. The deposition of the evaporites marks the latest phase of this low subsidence period. The sedimentary character indicate relative "tectonic quietness", without major extensional or compressional forces.

b. Late Badenian to Early Sarmatian (TST4 to HST5). Subsidence rates were high, compared to the previous phase. The sedimentary input and infill could hardly keep up with the accommodation space generated by the subsidence. Mainly deep marine environments are known. The sedimentation indicate an underfilled basin.

c. Late Sarmatian to Pannonian (LST6-HST8). Subsidence rates remain high, but the sedimentary input is highly increased due to the Carpathian's uplift. The basin was filled only during the Latest Pannonian and Pontian.

d. Pliocene uplift and regional south-east tilting of the basin triggered large scale erosion. Therefore the youngest basin fill of the basin (Late Pannonian and Pontian) was removed. 


\section{Acknowledgements}

We are grateful to National Agency for Mineral Resources (ANRM) and Romgaz S.A. for providing access to the primary data, and also to Dr. Orsolya Sztanó, Dr. Harry Doust, Dr. Daniel Ciulavu, and Dr. Gábor Bada for the very helpful comments and suggestions.

Csaba Krézsek thanks Dr. Liviu Mațenco for fruitful discussions, and colleagues from the Exploration Team of Romgaz for their support, especially to Laurențiu Ionescu and Aurel Pop.

This is a contribution to the research grants 169 funded by Romgaz S.A. and 28/180 funded by C.N.C.S.I.S. Romania.

\section{References}

Bada, G., 1999. Cenozoic stress field evolution in the Pannonian Basin and surrounding orogens: inferences from kinematic indicators and finite element modelling. PhD Thesis, Vrije Universiteit, Amsterdam. 204 pp.

Balintoni, I., Mészáros, N., Györfi, I., 1998. La Transylvanie, dépressions et bassins. Studia Universitatis Babeş-Bolyai. Seria Geologia XLIII (1), 43- 57.

Báldi, T., 1980. The early history of Paratethys. Földtani Közlöny 110/3-4, 456-472 (in Hungarian).

Báldi, K., Benkovics, L., Sztanó, O., 2002. Badenian (Middle Miocene) basin development in SW Hungary: subsidence history based on quantitative paleobathymetry of formaninifera. International Journal of Earth Sciences 91, 490-504.

Bally, A., Snelson, S., 1980. Realms of subsidence. In: Miall, A.D. (Ed.), Facts and Principles of World Petroleum Occurrence. Can. Soc. Geol. Mem., vol. 6, pp. 9 -94.

Burchfiel, B.C., 1976. Geology of Romania. Geological Society of America Special Paper 158 (82 pp.).

Cendon, D.I., Peryt, T.M., Ayora, C., Pueyo, J.J., Taberner, C., 2004. The importance of recycling processes in the Middle Miocene Badenian evaporite basin (Carpathian foredeep): palaeoenvironmental implications. Palaeogeography, Palaeoclimatology, Palaeoecology 212, $141-158$.

Ciulavu, D., 1999. Tertiary tectonics of the Transylvanian Basin. PhD Thesis, Vrije Universiteit, Amsterdam. 152 pp.

Ciulavu, D., Bertotti, G., 1994. The Transylvanian Basin and its Upper Cretaceous substratum. Romanian Journ. Tectonics 75 (2), 59- 64.

Ciupagea, D., Păucă, M., Ichim, T., 1970. Geology of the Transylvanian Depression. Romanian Academy Publishing House, Bucharest. 256 pp. (in Romanian).

Crânganu, C., Deming, D., 1996. Heat flow and hydrocarbon generation in the Transylvanian Basin, Romania. AAPG Bulletin 10, 1641-1653.

Csontos, L., 1995. Tertiary evolution of the Intracarpathian area: a review. Acta Vulcanologica 7, $1-15$.

De Broucker, G., Mellin, A., Duindam, P., 1998. Tectono-stratigraphic evolution of the Transylvanian Basin, pre-salt sequence, Romania. In: Dinu, C., Mocanu, V. (Eds.), Geological and Hydrocarbon Potential of the Romanian Areas, Bucharest Geosciences Forum, Spec., vol. 1, pp. 36-70.

Decker, K., 1996. Miocene tectonics at the Alpine-Carpathian junction and the evolution of the Vienna basin. Mitteilungen der Gesellschaft der Geologie- und Bergbaustudenten in Österreich $41,33-44$.

Dragoş, V., 1969. Contributions to the knowledge of evaporite genesis in the Transylvanian Basin. Studii şi Cercetări de Geologie, Geografie şi Geologie Seria geologie 14 (1), 163-180 (in Romanian). 
Dumitrică, P., Gheța, N., Popescu, Gh., 1975. New data on the biostratigraphy and correlation of the Middle Miocene in the Carpathian area. Dări de Seamă ale Sedintelor-Institutul de Geologie şi Geofizică 61, 65-84.

Filipescu, S., 1996. Stratigraphy of the Neogene from the western border of the Transylvanian Basin. Studia Universitatis Babeş-Bolyai. Seria Geologia XLI (2), 3 - 78.

Filipescu, S., 1999. The significance of foraminifera fauna from the Feleac Formation (Transylvanian Basin, Romania). Studia Universitatis Babeş-Bolyai. Seria Geologia XLIV (2), $125-131$.

Filipescu, S., 2001. Wielician foraminifera at the western border of the Transylvanian Basin. Studia Universitas Babeş-Bolyai. Seria Geologia XLV (2), 115-123.

Filipescu, S., 2004a. Agglutinated foraminifera to sequence stratigraphy- the case of Bogdanowiczia pocutica Pishvanova. In: Bubik, M., Kaminski, M.A. (Eds.), Proceedings of the Fifth International Workshop on Agglutinated Foraminifera, Grzybowski Foundation Special Publication, vol. 8, p. 460. Krakow.

Filipescu, S., 2004b. Anomalinoides dividens bioevent at the Badenian/Sarmatian boundary-a response to paleogeographic and paleoenvironmental changes. Studia Universitatis BabesBolyai Geologia. Cluj-Napoca XLIX (2), 21- 26.

Filipescu, S., Gîrbacea, R., 1994. Stratigraphic remarks on the Middle Miocene deposits from Garbova de Sus (Transylvanian Basin, Romania). Studia Universitatis Babeş-Bolyai. Seria Geologia XXXIX (1-2), 275- 286.

Filipescu, S., Gîrbacea, R., 1997. Lower Badenian sea-level drop on the western border of the Transylvanian Basin: foraminiferal palaeobathymetry and stratigraphy. Geologica Carpathica (Bratislava) 48 (5), 325- 334.

Filipescu, S., Popa, M., Wanek, F., 2000. The significance of some Sarmatian faunas from the southwestern part of the Pădurea Craiului Mountains (Romania). Acta Palaeontologica Romaniae II. (Proceedings of the Second Romanian Symposium on Paleontology, Cluj-Napoca 1999) pp. 163- 169.

Fodor, L., Csontos, L., Bada, G., Györfi, I., Benkovics, L., 1999. Tertiary tectonic evolution of the Pannonian Basin system and neighboring areas: a new synthesis of paleostress data. In: Durand, B., Jolivet, L., Horváth, F., Séranne, M. (Eds.), The Mediterranean Basins: Tertiary Extension Within the Alpine Orogene. Geol. Soc. Spec. Publ., London, vol. 156, pp. 295- 334.

Ghergari, L., Mészáros, N., Hosu, A., Filipescu, S., Chira, C., 1991. The gypsiferous formation at Cheia (Cluj County). Studia Universitatis Babeş-Bolyai. Seria Geologia XXXVI (1), 13-28.

Gîrbacea, R.,1997. The Pliocene to Recent tectonic evolution of the Eastern Carpathians (Romania), PhD Thesis, Tübinger Geowissenschaftliche Arbeiten (TGA), Tübingen, A-35. 136 $\mathrm{pp}$.

Gräf, I., Pană, I., Mitrea, Gh., 1973. New data on Pliocene biostratigraphy at north and southeast of Odorheiu Secuiesc (southeastern Transylvanian Basin). Studii si Cercetari de Geologie, Geofizica, Geografie. Seria Geologie 18 (2), 443-462 (in Romanian).

Györfi, I., Csontos, L., Nagymarosi, L., 1999. Early Tertiary structural evolution of the border zone between the Pannonian and Transylvanian basins. In: Durand, B., Kolivet, L., Horváth, F., Séranne, M. (Eds.), The Mediterranean Basins: Tertiary Extension Within the Alpine Orogene. Geol. Soc. Spec. Publ., London, vol. 156, pp. 251-268.

Haq, B.U., Hardenbol, J., Hardenbol, P.R., 1988. Mesozoic and Cenozoic chronostratigraphy and cycles of sea level changes. In: Wilgus, C.K., Hastings, B.S., Kendall, C.G.St.C., Posamentier, H.W., Ross, C.A., Van Wagooner, J.C. (Eds.), Sea-Level Changes-An Integrated Approach. SEPM Special Publication, vol. 42, pp. 71-108.

Horváth, F., 1995. Phases and compression during the evolution of the Pannonian Basin and its bearing hydrocarbon exploration. Marine Petroleum Geology 12, 837-844.

Horváth, F., Cloetingh, S., 1996. Stress induced late-stage anomalies in the Pannonian Basin. Tectonophysics 266, 287-300. 
Hosu, A., 1999. Sedimentary architecture of the Eocene deposits form the NW Transylvanian Depression, $\mathrm{PhD}$ thesis, Babeş-Bolyai University, Cluj-Napoca, 224 pp. (in Romanian).

Hosu, A., Filipescu, S., 1996. Sequence stratigraphy on the Middle-Miocene deposits from Gârbova de Sus (Transylvanian Basin, Romania). Studii şi Comunicări. Muzeul Județean Bistrița 1, 87-97.

Huismans, R., 1999. Dynamic modelling of the transition from passive to active rifting. PhD Thesis, Vrije Universiteit, Amsterdam, 182 pp.

Huismans, R., Bertotti, G., Ciulavu, D., Sanders, C.A.E., Cloething, S., Dinu, C., 1997. Structural evolution of the Transylvanian Basin (Romania): a sedimentary basin in the bend of the Carpathians. Tectonophysics 272, 249- 268.

Juhász, E., Kovács, L.Ó, Mü 1ler, P., Tóth-Makk, Á ., Phillips, L., Lantos, M., 1997. Climatically driven sedimentary cycles in the Late Miocene sediments of the Pannonian Basin, Hungary. Tectonophysics 282, 257-276.

Kasprzyk, A., Orti, F., 1998. Paleogeographic and burial controls on anhydrite genesis: the Badenian Basin in the Carpathian Foredeep (southern Poland, western Ukraine). Sedimentology 45, 889-907.

Koch, A., 1900. Die Tertiar-Bildingen des Beckens des Siebenbürgischen Landesteiles II. Neogen, Budapest. 370 pp.

Kováč, M., Baráth, I., Kováčová-Slamková,, Pipík, R., Hlavaty', I., Hudačková, N., 1998. Late Miocene paleoenvironments and sequence stratigraphy: northern Vienna Basin. Geologica Carpathica 49 (6), 445- 458.

Kováć, M., Holcová, K., Nagymarosi, A., 1999. Paleogeography, paleobathymetry and relative sea-level changes in the Danube Basin and adjacent areas. Geologica Carpathica 50 (4), 325338.

Kováč, M., Holcová, K., Zlinská, A., Nagymarosy, A., Hudačková, N., 2001. Paleogeography, paleoecology and eustacy: Miocene 3rd order cycles of relative sea-level changes in the Western Carpathian-North Pannonian Basins. Acta Geologica Hungarica 44 (1), 1 - 45.

Krézsek, Cs., 2001. Sedimentology of the Pannonian Deposits in the Niraj Valley Area. Collegium Geologicum, vol. 2. Erdélyi Múzeum Egyesület, Cluj Napoca, pp. 7- 33 (in Hungarian and Romanian).

Krézsek, Cs., 2004. Salt-Related Gravitational Gliding in Transylvania, Extended Abstract, AAPG Prague Conference 2004. 8 pp.

Krézsek, Cs., 2005. Sedimentology and architecture of the Pannonain deposits from the eastern Transylvanian Basin, unpublished $\mathrm{PhD}$ thesis, Babes-Bolyai University, Cluj-Napoca. $170 \mathrm{pp}$.

Krézsek, Cs., Bally, A.W., submitted for publication. The Transylvania Basin (Romania) and its relation to the Carpathians Fold and Thrust Belt: insights in gravitational salt tectonics. Marine and Petroleum Geology.

Lubenescu, V., 1981. Biostratigraphic study on the Upper Neogene from the south-western Transylvania. Anuarul Institutului de Geologie şi Geofizică Bucureşti LVIII, 123- 194 (in Romanian).

Lupu, D., Lupu, M., 1983. Biostratigraphische und fazielle Merkmale der "Gosauformation" im Apuseni Gebirge. Anuarul Institutului de Geologie şi Geofizică 59, 95-100.

Magyar, I., Geary, D.H., Mü 1ler, P., 1999a. Paleogeographic evolution of the Late Miocene Lake Pannon in Central Europe. Palaeogeography, Palaeclimatology, Paleoecology 147, 151- 167.

Magyar, I., Geary, D.H., Sütö-Szentai, M., Lantos, M., Mü 1ler, P., 1999b. Integrated biostratigraphic, magnetostratigraphic and chronostratigraphic correlations of the Late Miocene Lake Pannon deposits. Acta Geologica Hungarica 42/1, 5- 31.

Mațenco, L., 1997. Tectonic evolution of the outer Romanian Carpathians: constraints from kinematic analysis and flexural modeling. PhD Thesis, Univ. Vrije, Amsterdam. 160 pp. 
Márton, E., Fodor, L., 2003. Tertiary paleomagnetic results and structural analysis from the Transdanubian Range (Hungary): rotational disintegration of the Alcapa Unit. Tectonophysics 363, 201-227.

Mârza, I., Mészáros, M., 1991. Les tuffs volcaniques de Transylvanie: historique, valeur theorique et pratiqe dans le developpement de la geologie Transylvaine. In: Bedelean, I., Ghergari, L., Mârza, I., Mészáros, M., Nicorici, E., Petrescu, I. (Eds.), The Volcanic Tuffs from the Transylvanian Basin, Romania, Cluj Napoca, pp. $11-21$.

Mitchum Jr., R.M., 1985. Seismic stratigraphic expression of submarine fans. In: Berg, O.R., Woolverton, D.G. (Eds.), Seismic Stratigraphy II - an Integrated Approach, AAPG Mem., vol. 39, pp. 117- 136.

Mitchum Jr., R.M., Vail, P.R., Sangree, J.B., 1977. Stratigraphic interpretation of seismic reflection patterns in depositional sequences. In: Payton, C.E. (Ed.), Seismic StratigraphyApplications to Hydrocarbon Exploration, AAPG Mem., vol. 26, pp. 117- 143.

Moisescu, V., Popescu, Gh., 1967. Stratigraphic study of the Paleogene and Miocene in the region of Chinteni-Baciu-Sinpaul (northwestern Transylvania). Studii si Cercetari de Geologie, Geofizica, Geografie. Seria Geologie 12 (1), 211- 224 (in Romanian).

Müller, P., Geary, D.H., Magyar, I., 1999. The endemic molluscs of the Late Miocene Lake Pannon: their origin, evolution, and family-level taxonomy. Lethaia 32, 47-60.

Mutti, E., 1985. Turbidite systems and their relations to depositional sequences. In: Zuffa, G.G. (Ed.), Provenance of Arenites. D. Reidel Purl. Comp, pp. 65- 93.

Mutti, E., 1992. Turbidite Sandstones. AGIP Spec., Publ. Milano, 275 pp.

Mutti, E., Normark, W.R., 1991. An integrated approach to the study of turbidite systems. In: Weimer, P., Link, M.H. (Eds.), Seismic Facies and Sedimentary Processes of Submarine Fans and Turbidite Systems. Springer-Verlag, New York, pp. 75-106.

Panaiotu, C., 1998. Paleomagnetic constrains on the geodynamic history of Romania. In: Ioane, D. (Ed.), Monograph of Southern Carpathians, Reports on Geodesy, vol. 7(37), pp. 205-217.

Papp, A., Turnovsky, K., 1953. Die Entwicklung der Uvigerinen im Vindobon (Helvet und Torton) des Wiener Beckens. Jahrbuch der Geologischen Bundesantalt 96, 117- 142.

Pătraşcu, Ş t., Panaiotu, C., Ş eclăman, M., Panaiotu, C.E., 1994. Timing of rotational motions of Apuseni Mountains (Romania): paleomagnetic data from Tertiary magmatic rocks. Tectonophysics 233, 163- 176.

Pécskay, Z., Lexa, J., Szakács, A., Balogh, K., Seghedi, I., Konecny, V., Kovács, M., Márton, E., Kaliciak, M., Széky-Fux, V., Póka, T., Gyarmati, P., Edelstein, O., Roşu, E., Zec, B., 1995. Space and time evolution of the Neogene-Quaternary volcanism in the Carpatho-Pannonian Region. Acta Vulcanologica 7 (2), 15- 28.

Pervesler, P., Hohenegger, J., Rö gl, P., Peryt, T., Michalik, J. (Eds.), 2004. Marine Middle Miocene in the Alpine-Carpathian Foredeep, Geologica Carpathica, vol. 55 (2) 86 pp.

Peryt, T.M., 2001. Gypsum facies transitions in basin-marginal evaporites: Middle Miocene (Badenian) of west Ukraine. Sedimentology 48, 1103-1119.

Peryt, T.M., 2002. S and O isotopic composition of the Badenian (Middle Miocene) sulphates in the Carpathian Foredeep. Geologica Carpathica 53, 391- 398.

Pogácsás, Gy., Lakatos, L., Révész, I., U’ jszászi, K., Vákarcs, G., Várkonyi, L., Varnai, P., 1988. Seismic facies, electro facies and Neogene sequence chronology of the Pannonian Basin. Acta Geologica Hungarica 31, 175-207.

Popescu, Gh., 1972. Biostratigraphy of the Oligocene-Miocene deposits from south of Preluca based on planctonic formanifera. Dări de Seamă ale de Sedintelor- Institutul de Geologie şi Geofizică LVIII (3), 105-127 (in Romanian).

Popescu, Gh., 1979. Kosovian foraminifera in Romania. Memoriile Institutului de Geologie şi Geofizică XXIX, 5 - 64. 
Popescu, Gh., Brotea, D., 1994. Evolution of the Transylvanian foraminiferal assemblages during Late Oligocene and Middle Miocene. In: Nicorici, E., Petrescu, I., Mészáros, N., Bedelean, I. (Eds.), The Miocene from the Transylvanian Basin, Romania, pp. 119- 124.

Posamentier, H.W., Vail, P.R., 1988. Eustatic controls on clastic deposition II - sequence and system tracts models. In: Wilgus, C.K., Hastings, B.S., Kendall, C.G.St.C., Posamentier, H.W., Ross, C.A., Van Wagooner, J.C. (Eds.), Sea-Level Changes: an Integrated Approach, SEPM Spec. Publ., vol. 42, pp. 125- 154.

Proust, J.N., Hosu, A., 1996. Sequence stratigraphy and Paleogene tectonic evolution of the Transylvanian Basin (Romania, easternEurope). Sedimentary Geology 105, 117- 140.

Ratschbacher, L., Frisch, W., Linzer, H.-G., Merle, O., 1991. Lateral extrusion in the eastern Alps: Part II. Structural analysis. Tectonics 10, 257-271.

Reading, H., Richards, M., 1994. The classification of deep-water siliciclastic depositional systems by grain size and feeder systems. American Association of Petroleum Geologists Bulletin 78, $792-822$.

Rögl, F., 1998. Paratethys Oligocene-Miocene stratigraphic correlation. In: Cicha, F., et al., (Eds.), Oligocene to Miocene Foraminifera of the Central Paratethys, Abhhandlungen der Senckbergishen Naturforschenden Gesellschaft, vol. 549, pp. $3-7$.

Royden, L., 1988. Late Cenozoic tectonics of the Pannonian basin system. In: Royden, L., Horváth, F. (Eds.), The Pannonian Basin: a Study in Basin Evolution, American Association of Petroleum Geologists Memoir, vol. 45, pp. 27- 48.

Rusu, A., 1995. Eocene formations in the Călata region (NW Transylvania): a critical review. Romanian Journal of Tectonics and Regional Geology 76, 59- 72.

Sacchi, M., Horváth, F., Magyari, O., 1999. Role of unconformity bounded units in the stratigraphy of the continental record: a case study from the Late Miocene of the western Pannonian Basin, Hungary. In: Durand, B., Jolivet, L., Horváth, F., Séranne, M. (Eds.), The Mediterranean Basins: Tertiary Extension Within the Alpine Orogen. Geol. Soc. Spec. Publ., London, vol. 156, pp. 357-390.

Sachsenhofer, R.F., 1996. The Neogene Styrian Basin: an overview. Mitteilungen der Gesellschaft der Geologie- und Bergbaustudenten in Österreich 41, 19- 32.

Sanders, C.A.E., 1999. Tectonics and erosion. Competitive forces in a compressive orogen. A fission track study of the Romanian Carpathians. PhD thesis, Vrije Universiteit, Amsterdam. $204 \mathrm{pp}$.

Săndulescu, M., 1984. Geotectonics of Romania. Romanian Academy Publishing House, Bucharest. 334 pp. (in Romanian).

Săndulescu, M., 1988. Cenozoic tectonic history of the Carpathians. In: Royden, L., Horváth, F. (Eds.), The Pannonian Basin: a Study in Basin Evolution, American Association of Petroleum Geologists Memoir, vol. 45, pp. 17- 25.

Săndulescu, M., Kra“utner, H., Borcoş, M., Năstăseanu, S., Patrulius, D., Ş tefănescu, M., Ghenea, C., Lupu, M., Savu, H., Bercea, I., Marinescu, F., 1978. Geological map of Romania, scale 1: 1,000,000. Institute of Geology and Geophysics, Bucharest.

Seghedi, I., Szakács, A., 1991. The Dej Tuff from Dej-Ciceu area: some petrographical, petrochemical and volcanological aspects. In: Bedelean, I., Ghergari, L., Mârza, I., Mészáros, M., Nicorici, E., Petrescu, I. (Eds.), The Volcanic Tuffs From the Transylvanian Basin, Romania, Cluj Napoca, pp. 135-146.

Steininger, F.F., Wessely, G., 2000. From the Tethyan Ocean to the Paratethys Sea: Oligocene to Neogene stratigraphy, paleogeography and paleobiogeography of the circum-Mediterranean region and the Oligocene to Neogene basin evolution in Austria. Mittelungen der Österreichischer Geologische Gesellschaft Wien 92, 95- 116.

Szakács, A., Seghedi, I., 1995. The Călimani-Gurghiu-Harghita volcanic chain, East Carpathians, Romania: volcanological features. Acta Vulcanologica 7 (2), 145- 153. 
Tărăpoancă, M., 2004. Arhitecture, 3D geometry and tectonic evolution of the Carpathians foreland basin. PhD Thesis, Vrije Universiteit, Amsterdam. $119 \mathrm{pp}$.

Tari, G., 1994. Alpine tectonics of the Pannonian Basin. PhD Thesis, Rice University, Houston, Texas. $501 \mathrm{pp}$.

Tari, G., Horváth, F., 1995. Middle Miocene extensional collapse in the Alpine-Pannonian transition zone. In: Horváth, F., Tari, G., Bokor, Cs. (Eds.), Hungary: Extensional Collapse of the Alpine Orogene and Hydrocarbon Prospects in the Basement and Basin Fill of the Western Pannonian Basin, American Association of Petroleum Geologists International Conference and Exhibition, 10-13 September, Nice, 6th Field Trip Notes, pp. 75-105.

Tari, G., Dövényi, P., Dunkl, I., Horvath, F., Lenkey, L., Ş tefănescu, M., Szafián, P., Toth, T., 1999. Lithospheric structure of the Pannonian basin derived from seismic, gravity and geothermal data. In: Durand, B., Jolivet, L., Horváth, F., Seranne, M. (Eds.), The Mediterranean Basins: Tertiary Extension Within the Alpine Orogen, Geol. Soc. Spec. Publ., London, vol. 156, pp. 215-250.

Vail, P.R., 1987. Seismic stratigraphic interpretation procedure. In: Bally, A.W. (Ed.), Atlas of Seismic Stratigraphy 1, AAPG Stud. Geol., vol. 27, pp. 1-10.

Vail, P.R., Mitchum Jr., R.M., Todd, R.G., Widmier, J.M., Thompson, S., Sangree, J.B., Bubb, J.N., Hatlelid, W.G., 1977. Seismic stratigraphy and global changes of sea level. In: Payton, C.E. (Ed.), Seismic Stratigraphy-Application to Hydrocarbon Exploration, AAPG Mem, vol. 26, pp. 49- 212.

Vakarcs, G., Vail, P.R., Tari, G., Pogácsás, Gy., Mattick, R.E., Szabó, A., 1994. Third-order Middle Miocene-Early Pliocene depositional sequences in the prograding delta complex of the Pannonian Basin. Tectonophysics 240, 81-106.

Vakarcs, G., Hardenbol, J., Abreu, V.S., Vail, P.R., Várnai, P., Tari, G., 1998. Oligocene-Middle Miocene depositional sequences of the Central Paratethys and their correlation with regional stages. In: Graciansky, P.Ch., Hardenbol, J., Jacquin, T., Vail, P.R. (Eds.), Mesozoic and Cenozoic Sequence Stratigraphy of European Basins, SEPM Spec. Publ., vol. 60, pp. 209231.

Van Wagooner, J.C., Posamentier, H.W., Mitchum, R.M., Vail, P.R., Sarg, J.F., Loutit, T.S., Hardenbol, J., 1988. An overview of the fundamentals of sequence stratigraphy and key definitions. In: Wilgus, C.K., Hastings, B.S., Kendall, C.G.St.C.,

Posamentier, H.W., Ross, C.A., Van Wagooner, J.C. (Eds.), Sea-Level Changes: an Integrated Approach, SEPM Spec. Publ., vol. 42, pp. 39-45.

Van Wagooner, J.C., Mitchum Jr., R.M., Campion, K.M., Rahmanian, V.D., 1990. Siliciclastic sequence stratigraphy in well-logs, cores and outcrops. AAPG Meth. Explor. Ser., vol. 7. 55 pp.

Vancea, A., 1960. Neogene of the Transylvanian Basin. Romanian Academy Publishing House, Bucharest. 262 pp. (in Romanian).

Wanek, F., 1992. Biostratigraphy of the Sarmatian and Pannonian ostracods from the Transylvanian Basin. Babes-Bolyai University Report, ROMGAZ Archive, Manuscript, 49 pp. (in Romanian).

Willingshofer, E., Neubauer, F., Cloetingh, S., 1999. The significance of Gosau-type basins for the Late Cretaceous tectonic history of the Alpine-Carpathians Belt. Physics and Chemistry of the Earth. Part A: Solid Earth and Geodesy 24 (8), 687- 695.

Willingshofer, E., Andriessen, P., Cloetingh, S., Neubauer, F., 2001. Detrital fission track thermochronolgy of Upper Cretaceous synorogenic sediments in the South Carpathians (Romania): inferences on the tectonic evolution of a collisional hinterland. Basin Research 13, 379-395.

Zweigel, P., 1997. The Tertiary tectonic evolution of the Eastern Carpathians (Romania): orogenic arc formation in response to microplate movements., PhD thesis, Univ. Tübingen. 158 pp. 


\section{Figures}

Fig. 1. Location map of the Paratethyan area and the Transylvanian Basin (black circle). The Miocene European basins belong to the Western Paratethys (molasse basins north of the Alpine orogen), Central Paratethys (in general, the Intra-Carpathian basins, east to the Alps and north to the Dinarides), and Eastern Paratethys (East of the Carpathians).

Fig. 2. Major stratigraphic units of the Transylvanian Basin (based on Săndulescu et al., 1978): 1Quaternary, 2-Pannonian, 3-Sarmatian, 4-Badenian, 5-Lower Miocene, 6-Neogene volcanics, 7pre-Miocene; also shown: position of the seismic profiles (Figs. 5, 7, 8 and 9), well correlation panel (Fig. 4); part of Pannonian Basin-East European (Moldavian) Platform regional transect (Fig. 6).

Fig. 3. Seismic and log facies (SP) of the Kosovian submarine fans. The seismic facies patterns fit well with the different SP log facies characteristics. Upper right: chaotic and channeled seismic facies characteristic for proximal fans. Upper left: Proximal to mid fan lobes are indicated by parallel, relatively strong and continuous reflections. The SP log trends indicate coarsening upward successions. Lower left: the mid to distal fan lobes seismic response is very similar to the previous, but with lower amplitudes. At large scale the SP shows an upward coarsening trend. Lower right: transparent to nearly parallel, very low amplitude reflections characterize the distal to outer fan lobes. The SP facies and core data also, indicate thin bedded turbidites and pelagics, with rare and small coarsening upward cycles.

Fig. 4. Well correlation panel in south-east Transylvania (see Fig. 1). Submarine fans of the Late Badenian transgressive system tract (TST4) are arranged in overall retrogradational pattern. This pattern changes into progradational during the HST4. The transgressive character of the Early Sarmatian is clearly visible (TST5). They are represented by deep (hundreds of meters) marine thin bedded turbidites, with a characteristic microfauna (Anomalinoides dividens Biozone). Note the Badenian/Sarmatian boundary is placed inside the transgression. Channel incision and prograding shallow ramp environment characterize the Early Sarmatian LST6. The retrogradational pattern of the TST6 deposits is obvious on the log facies: several upward fining cycles build an upward deepening succession. This is followed by progradational deltaic and ramp sediments (HST6).

Fig. 5. Seismic profile A-B (see Fig. 2) flattened at the Badenian/Sarmatian boundary (Top Badenian). The Lower Badenian sediments are to thin to be interpreted in detail on seismics. The Middle Badenian salt (LST4), and probably Lower Badenian sediments also, fills erosional troughs developed during the Early Miocene. Well developed Upper Badenian onlaps the submarine highs (sites of condensation). The Upper Badenian transgressive systems tract is formed by mud-sand dominated submarine lobes, arranged in overall retrogradational pattern. Proximal sandy submarine fan lobes compose the Upper Badenian lowstand systems tract (LST5). Note, the Badenian/Sarmatian boundary is situated inside the TST5. Coarse grained proximal submarine fans visible between 750-900 m (MD) of Well 8, belong to the Early Sarmatian lowstand systems tract (LST8).

Fig. 6. West-east oriented regional transect (I-II; please refer to Fig. 2) between the Transylvanian Basin and Moldavian Platform showing the inferred paleogeography of the Upper Badenian transgressive systems tract (TST3, Table 1). The southern Eastern Carpathians accretionary wedge was below the sea level, locally forming shallow marine platforms. These shallow marine deposits were eroded because of the Late Miocene to Pliocene uplift of the Carpathians (at least $3 \mathrm{~km}$ of uplift was interpreted based on fission track data; Sanders, 1999). Dysoxic to anoxic conditions 
prevailed during the early transgression (TST3) in the deepest back-arc and foreland basins (bituminous shales), also indicated by microfauna assemblages (planctonics only). During the subsequent highstand systems tract (HST3) the submarine fans were prograding toward the deepest troughs, the submarine highs representing sites of condensation. South-western and north-eastern sediment sources were interpreted.

Fig. 7. Seismic line $\mathrm{C}-\mathrm{D}$. The seismic line represents a roughly transversal cross-section ("strike line") of the Sarmatian clinoforms (better visible on dip lines: Fig. 8). Large scale submarine channel incision during the Late Badenian lowstand systems tract (LST5) occurred in the previous highstand (HST4) slope turbidites (visible in the center of the profile). Well developed inclined reflections downlap the erosional surface (base of channel system), indicating eastward (to the right) channel migration.

Fig. 8. Seismic line E-F. bDipQ line of the Sarmatian large scale progradation. Large scale relative sea level fall initiated the lowstand systems tract (LST5) during the Early Sarmatian. Large scale erosion occurred: deposits of TST5-HST5 preserved in Well 9, are missing in Well 10 and 11. During the lowstand, while the area of Well 9 was eroded, lowstand submarine fans were deposited (visible on SP logs of Well 10 and 11, around $900 \mathrm{~m}$ ). The subsequent transgressive systems tract deposits are indicated by well developed onlaps on the sequence boundary, by the well log patterns (fining upward, see Well 9) and lithology also (finer deposits).

Fig. 9. Seismic line G-H. Large-scale erosional surface dominates the upper half of the seismic line. The erosion is related to the relative sea-level fall of the Late Sarmatian (LST7). The MLM7 sequence is mainly built by deep marine submarine fan deposits. The unconformity was tentatively interpreted as large scale submarine erosional surface (channel margin?) also strongly linked to salt-tectonics driven inversions. The section shows salt-tectonics influence, very important starting with the Late Badenian. During the Sarmatian, increased compressional stress field related to Carpathian tectonic paroxysm triggered active salt-withdrawal, creating several turtle structures in the eastern part of the basin. In our figure, the MLM6 sequence consists of submarine fan deposits channeled between- and depositionally onlapping- the salt-cored highs. The sediments are tilted toward east (right) because of the salt-withdrawal processes.

\section{Plates}

Plate 1. Foraminifera in sequence MLM2. 1-3 oportunist species: 1-Ammonia beccarii (Linné), 2Lobatula lobatula (Walker and Jakob), 3-Sigmoilinita tenuis (Czjzek); 4-Orbulina suturalis (Brönnimann); 5-20 shoreface to offshore species: 5-Spirorutilus carinatus (d'Orbigny), 6Amphicoryna hispida (Soldani), 7-Marginulina hirsuta (d'Orbigny), 8-Laevidentalina elegans (d'Orbigny), 9-Neugeborina longiscata (d'Orbigny), 10-Bulimina subulata (Cushman and Parker), 11-Bitubulogenerina reticulata (Cushman), 12-Uvigerina asperula Czjzek, 13-Elphidium fichtelianum (d'Orbigny), 14-Praeglobobulimina pyrula (d'Orbigny), 15-Globulina punctata (d'Orbigny), 16-Uvigerina pygmoides (Papp and Turnowski),17-Loxostomum digitalis (d'Orbigny), 18-Bolivina antiqua (d'Orbigny),19-Valvulineria complanata (d'Orbigny), 20Ceratocancris haueri (d'Orbigny). (1, 15-after Filipescu, 1996; 5, 6, 7, 9, 16, 17, 18-after Filipescu and Gîrbacea, 1994; 13-after Filipescu and Gîrbacea, 1997).

Plate 2. Foraminifera in sequences MLM2 and MLM3. 1-8 large species in foreshore, upper shoreface and lagoon settings, sequence MLM2: 1- Alveolophragmium crassum (Reuss), 2Quinqueloculina buchiana (d'Orbigny), 3-Cornuspira plicata (Czjzek), 4-Eponides repandus (Fichtel and Moll), 5-Amphistegina hauerina d'Orbigny; 6-Elphidium crispum (Linné), 7Planostegina costata (d'Orbigny), heavily ornamented specimen, 8-Planostegina costata 
(d'Orbigny), common specimen; 9-14 offshore species, sequence MLM3: 9-Pullenia bulloides (d'Orbigny); 10-Uvigerina orbignyana (Czjzek), 11-Uvigerina pudica (Luczkowska), 12-Uvigerina semiornata (d'Orbigny), 13-Reussella spinulosa (Reuss); 14-Melonis pompilioides (Fichteland Moll). (1, 3, 7-after Filipescu, 1996; 6-after Filipescu and Gîrbacea, 1994; 8-after Filipescu and Gîrbacea, 1997; 9-14-after Filipescu, 2001).

Plate 3. Foraminifera and ostracods in sequences MLM4 to MLM8. 1-4 microflora and microfauna in sequence MLM4: 1-diatoms, 2-pteropod (Limacina), 3-Velapertina indigena (Luczkowska), 4-Bogdanowiczia pocutica (Pishvanova); 5-10 microfauna in the Sarmatian, sequences MLM5 and MLM6: 5-Anomalinoides dividens (Luczkowska), 6-Pseudotriloculina consobrina (d'Orbigny), 7-Elphidium aculeatum (d'Orbigny), 8-Nonion bogdanowiczi (Voloshinova), 9-Sarmysis vancouveringi (Voicu) (d'Orbigny), 10-Porosononion granosum (d'Orbigny); 11-15 microfauna in sequences MLM7 and MLM8: 11-Bolivina moldavica (Didkovski), 12-Porosononion aragviensis (Djanelidze), 13-Amplocypris reticulata (Hejjas), 14Lineocypris transilvanica (Hejjas), 15-Caspiocypris laevis (Hejjas). (7,8-after Filipescu et al., 2000; 10,13,14,15-after Filipescu, 1996; 12-after Filipescu, 1999).

\section{Table}

Table 1 Synthetic stratigraphic data for the Transylvanian Basin

*Based on Pervesler et al. (2004).

**Based on Haq et al. (1988).

Depositional settings: 1. littoral; 2. outer ramp; 3. mixed platform; 4. deeper marine (hundreds of meters); 5. outer ramp; 6. platform and sabkha gypsum; 7. outer ramp halite; $8-9$ ramp?; 10. deep marine, anoxic; 11. outer ramp (condensation); 12. submarine fan, deep marine; 13. littoral/ ramp; 14. deep marine; 15. outer ramp; 16. deep marine fans; 17. ramp, lagoon; 18. deep marine condensation; 19. delta; 20. fandelta; 21. deep lacustrine? fan; 22. outer ramp; 23. deep lacustrine condensation; 24. inner ramp; 25. lacustrine fans; 26. fandelta; 27. deep lacustrine fans; 28. proximal ramp delta; 29. deep lacustrine fans. 


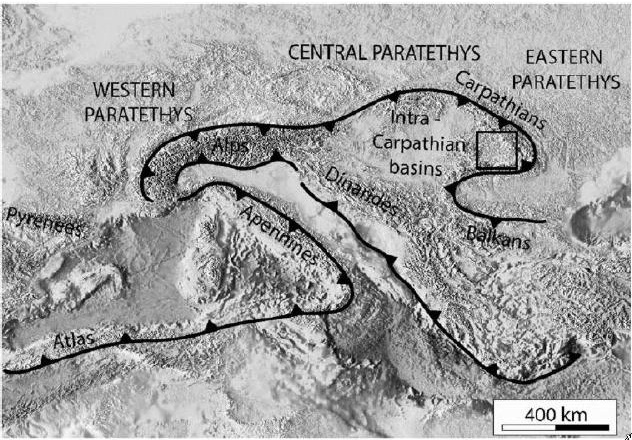


Fig. 2

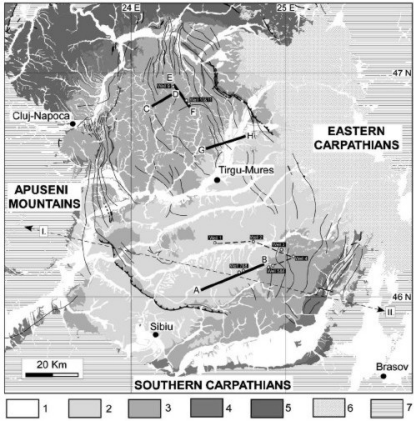

- w Well corelation panel (Fa. 4)

- Regional transect (Fig. 6) (shows only the section between the east Apuseni Mits and westem Easien Carpaitians)

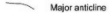

C.... inverse lauli 
Fig. 3

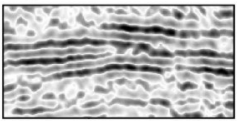

Proximal fan (only seismic facies shown)

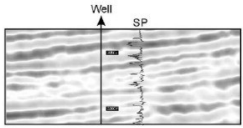

Mid to distal fan

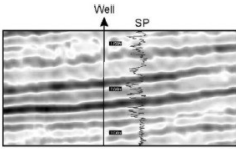

Proxmal to mid fan

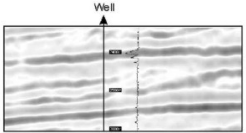

Distal to outer tan; +i- mictan lobes

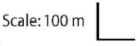


Fig. 4

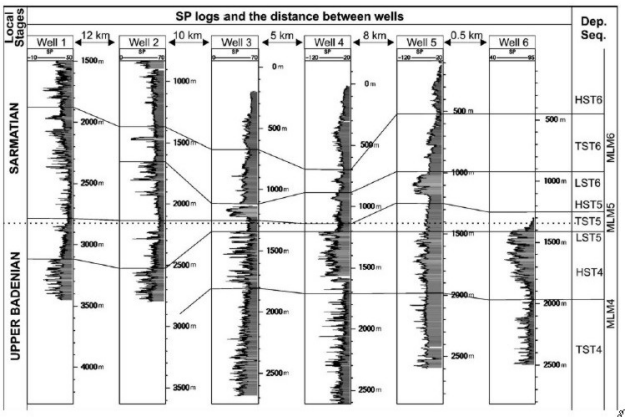


Fig. 5

Seismic line A-B flattened on Top Badenian

A

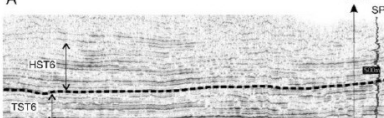

Well 7

4 SP

trex

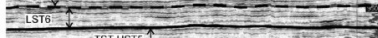

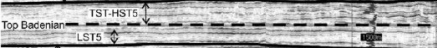

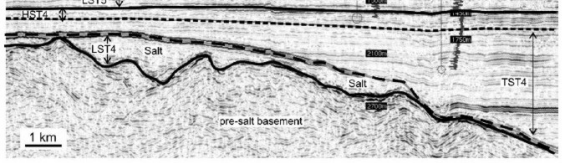

Sequence boundary

- - - Transgressive surface

...... Maximum flooding surface 


\section{Fig. 6}

PANNONIAN

BASIN

APUSENI TRANSYLVANIAN BASIN
MOUNTAINS

CARPATIANS FORELAND

PLATFORM

Starved basin

very Imiled secimentary inpu

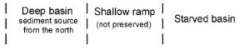

Shallow marine

Sea-level

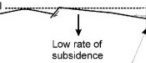

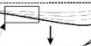

High rate of subsidence

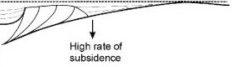

Seismic line (Fig. 5)

Not to scale! 
Fig. 7

C

Seismic line C-D

$\mathrm{ms}$
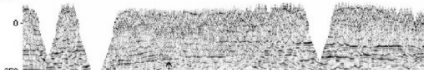

D

250

500 Sot 15 ist-AsT5

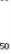

$\frac{1}{\mathrm{HST} 4}=1$

750
1000

$2-2$

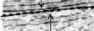

IST 4 -
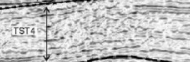

Tit
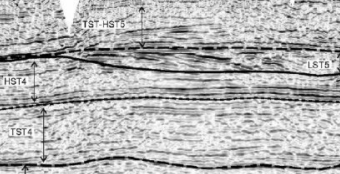

LSTA

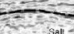

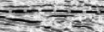

Lists

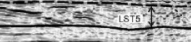

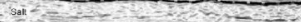

1250 -

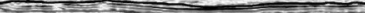

= pre-Badenian basement

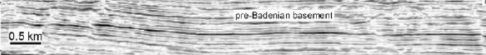

Sequence boundary

Transgressive surface

Maximum flooding surface 
Fig. 8

Seismic line E-F

$E$

Well 9

Well 10

Well 11

SPA

$\mathrm{sp} \wedge$

$\operatorname{sp} 4$

ms

HSTE 3 , vin

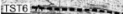

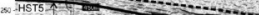

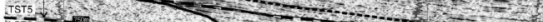

एख़ा

$50:$

LST5 $\frac{100}{10}$

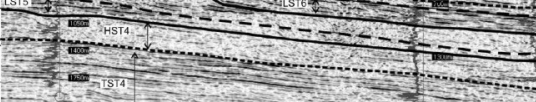

126

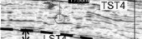

1509
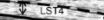
Sarte

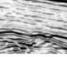

Sequence boundary

- - - Transgressive surface

...... Maximum flooding surface 


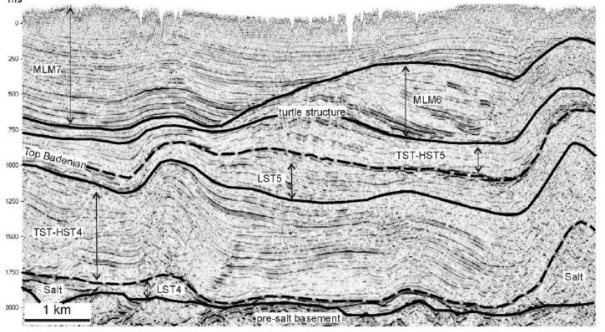



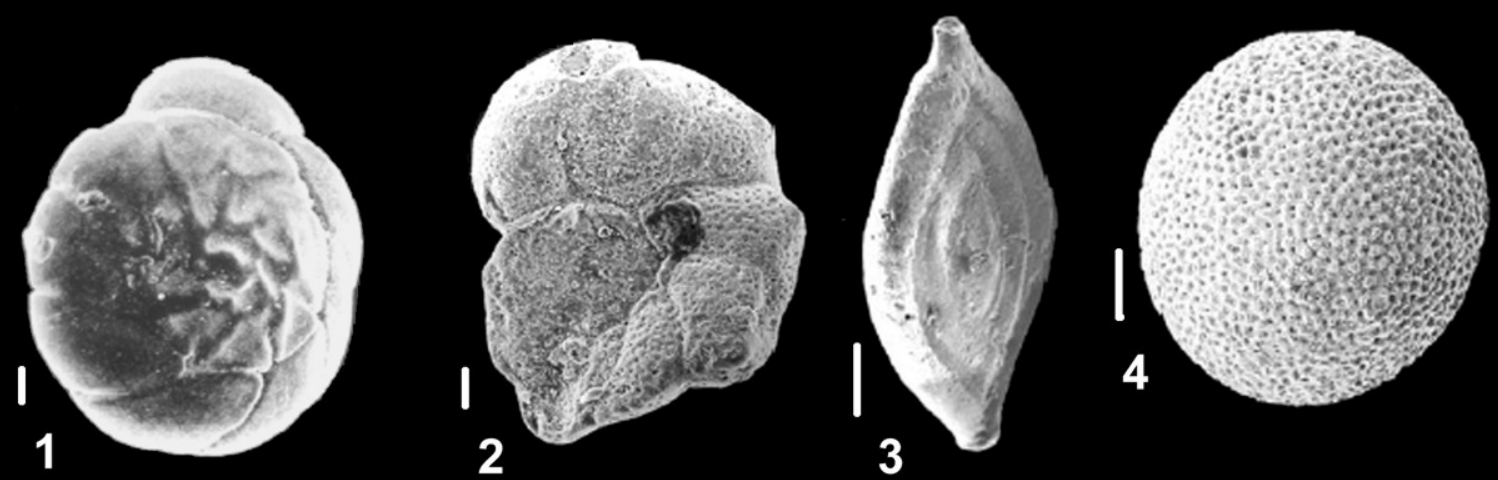

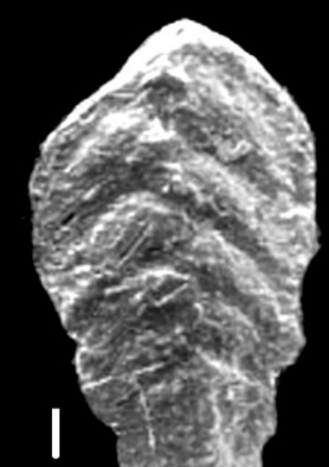

5
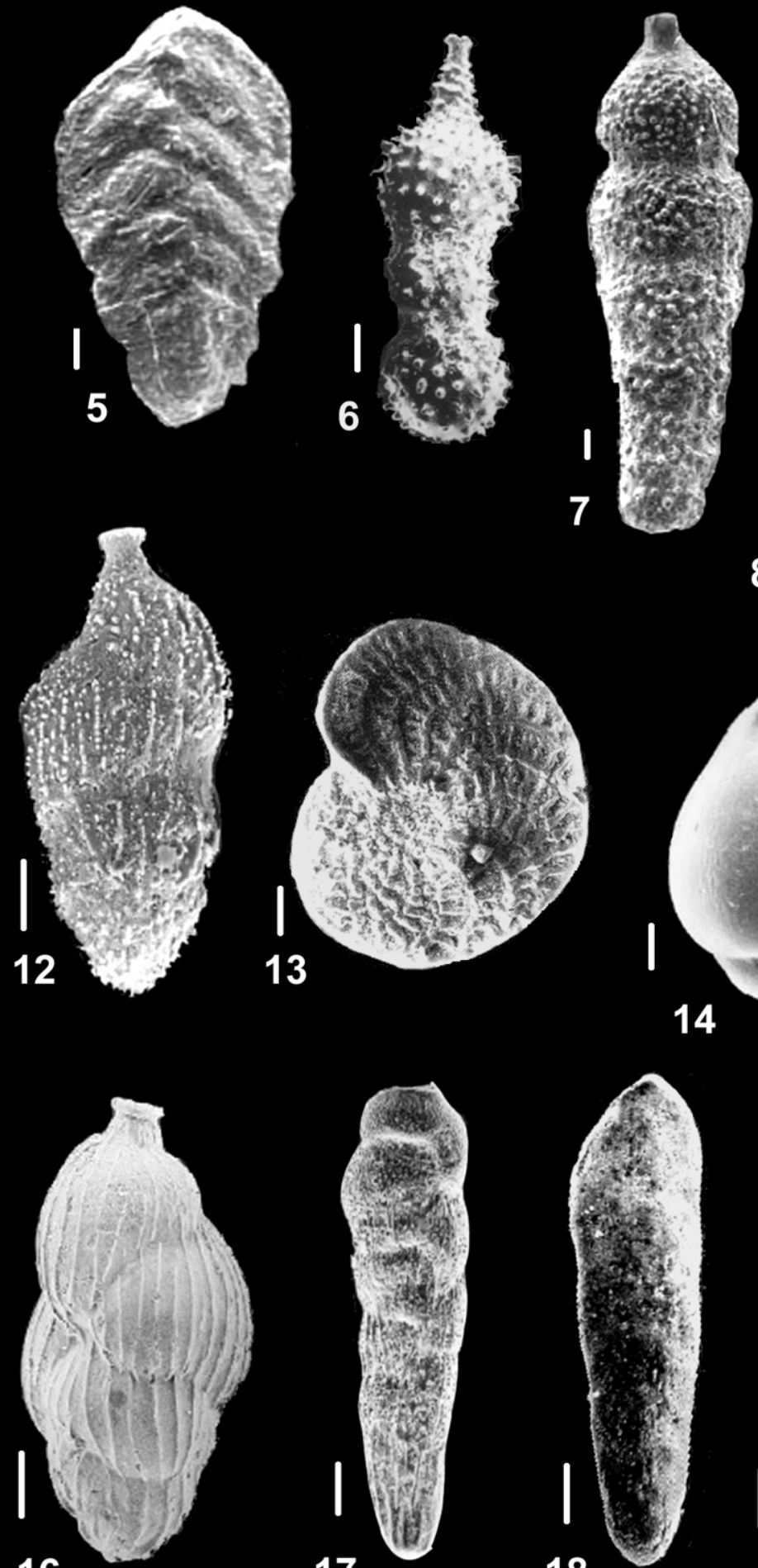

16
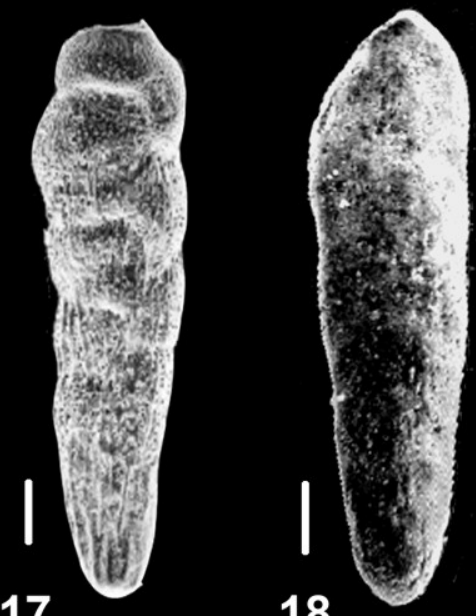

18

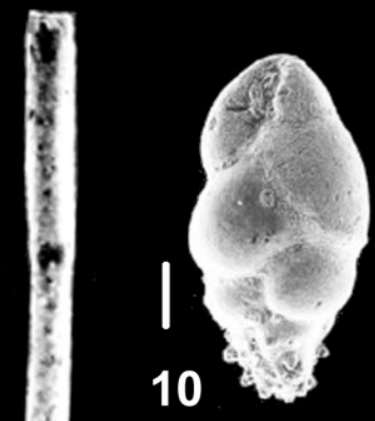

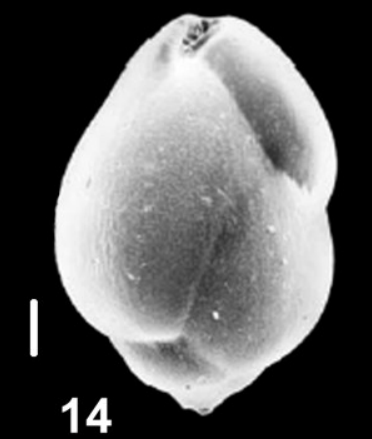

8

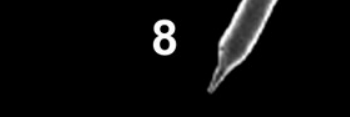

9
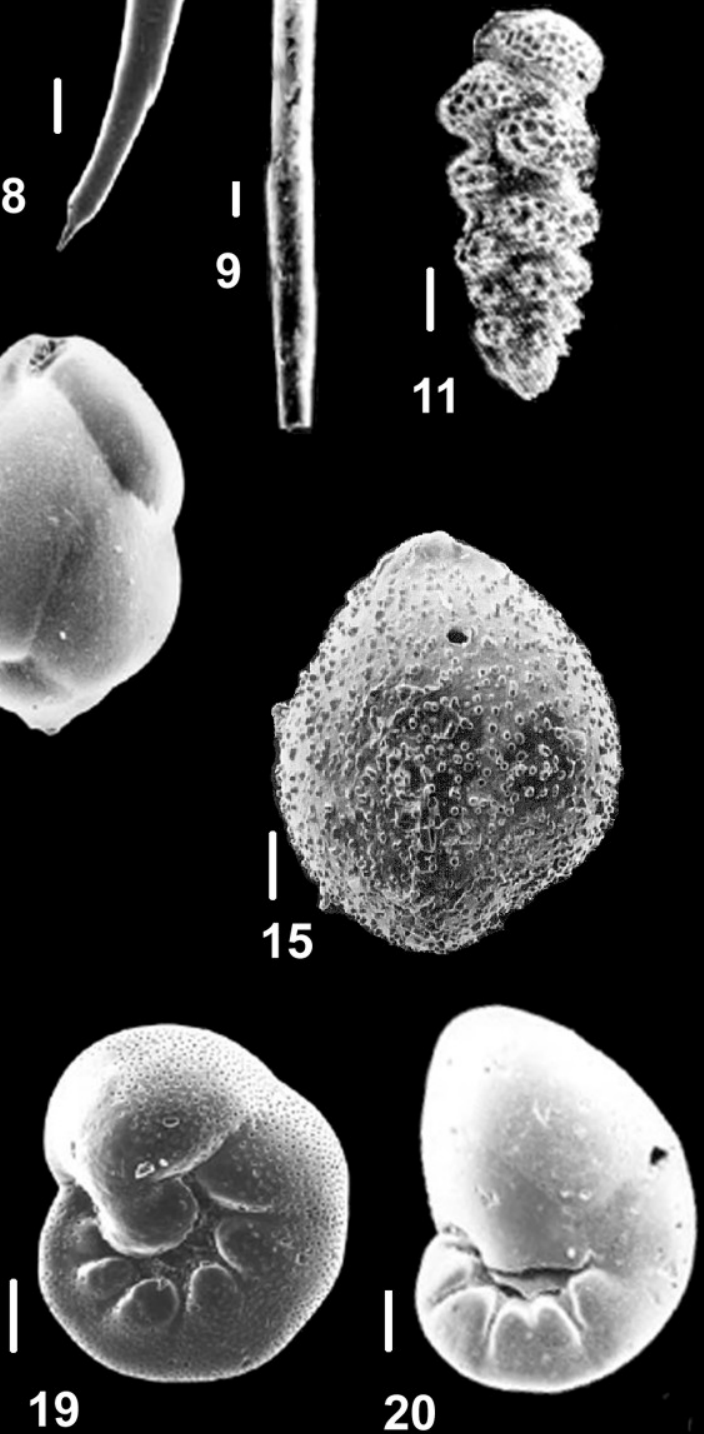

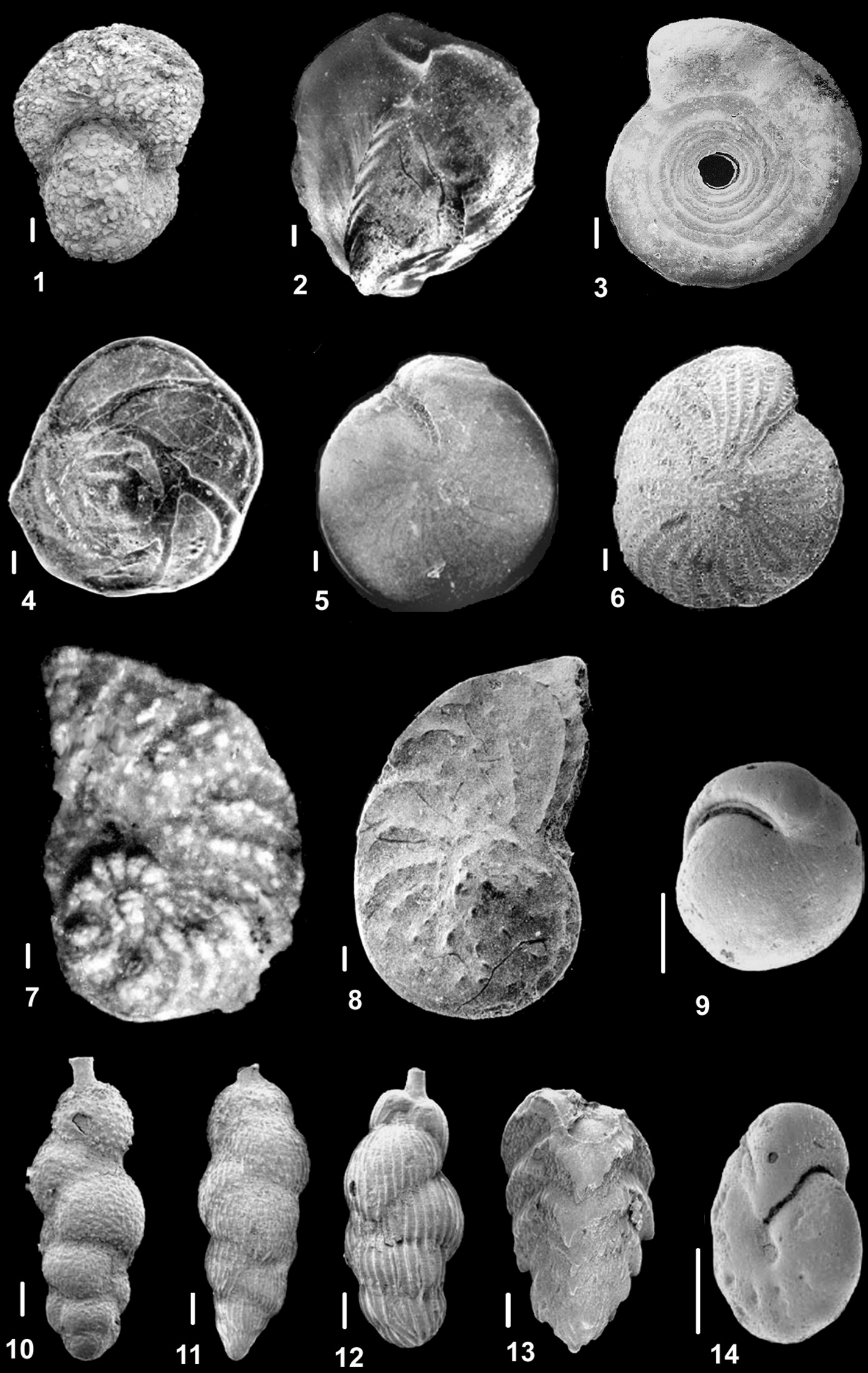

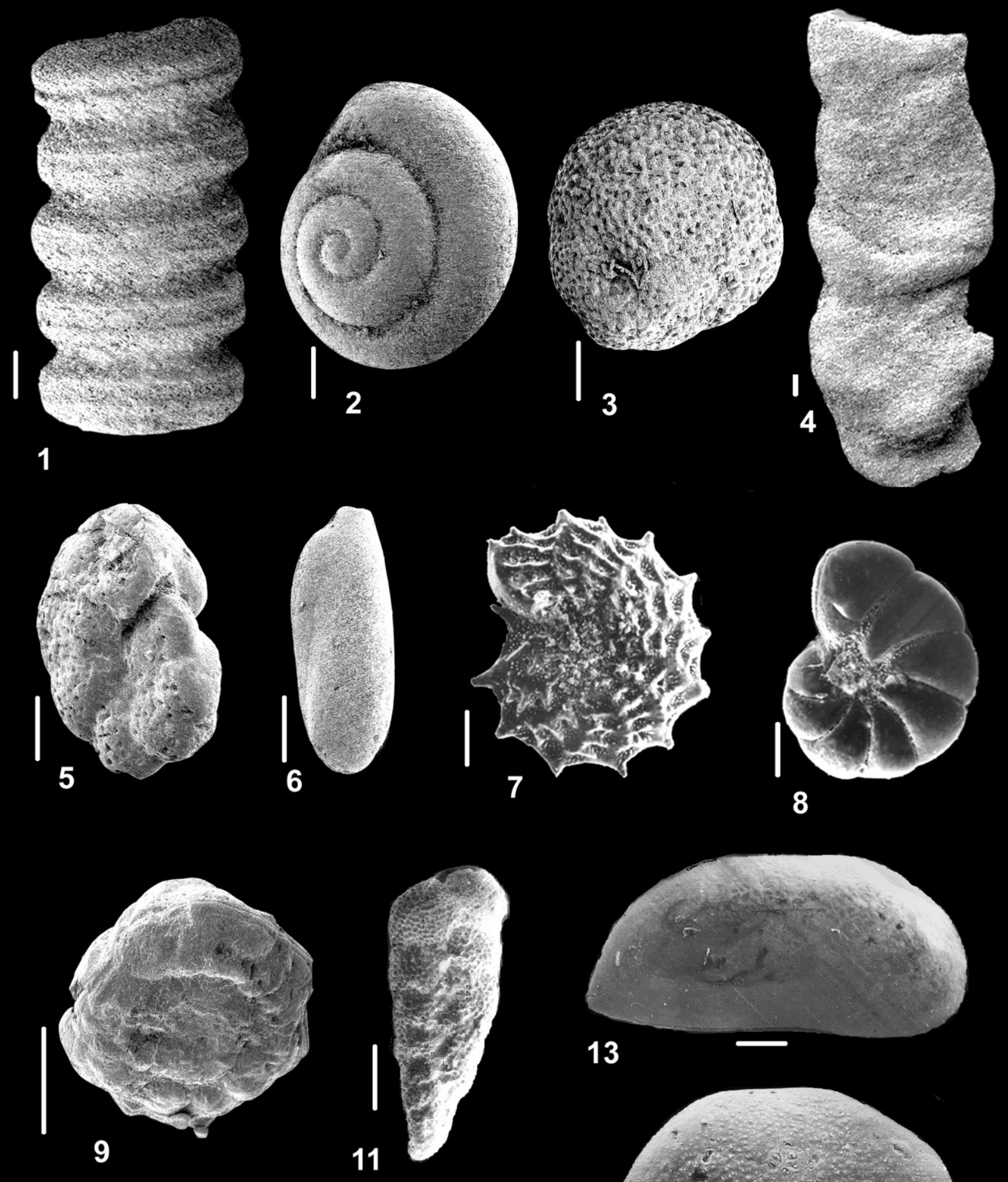

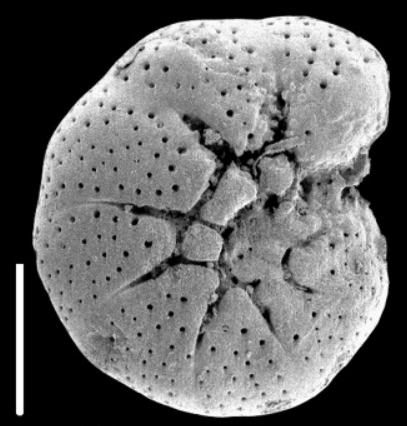

10

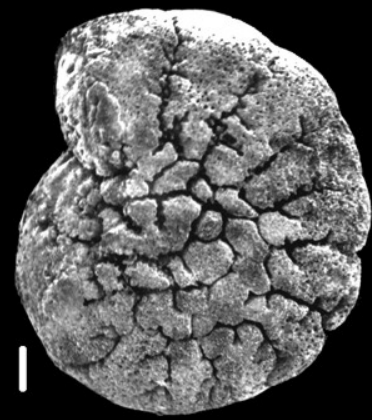

12

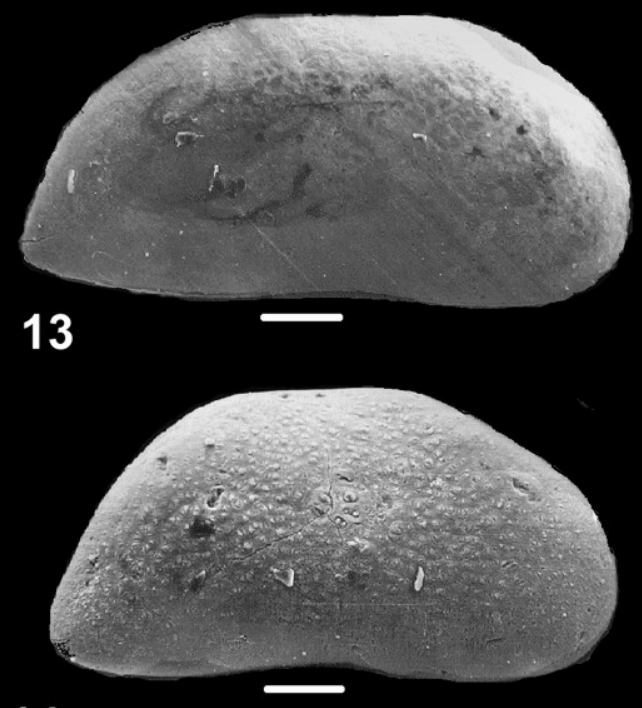

14

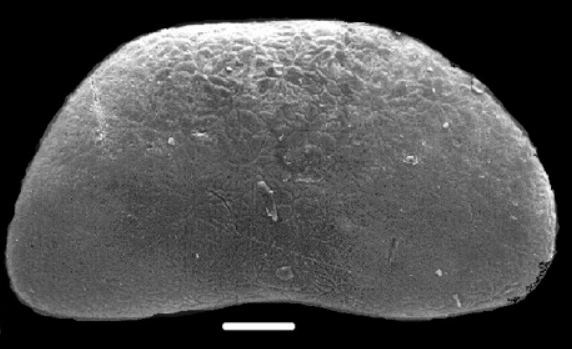




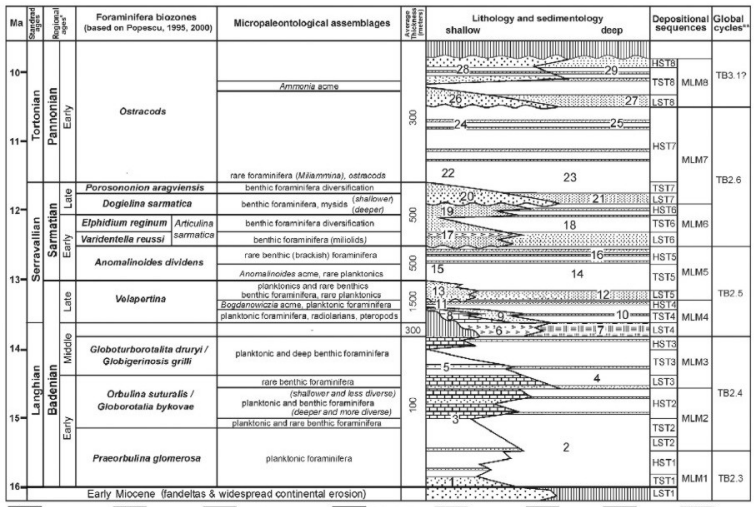

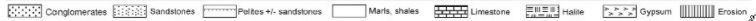

